\title{
The Role of Inflammation in the Pathogenesis of Idiopathic Pulmonary Fibrosis
}

\author{
BENJAMIN D. BRINGARDNER, CHRISTOPHER P. BARAN, TIMOTHY D. EUBANK, and CLAY. \\ B. MARSH \\ Department of Internal Medicine, Division of Pulmonary, Allergy, Critical Care, and Sleep Medicine, \\ The Dorothy M. Davis Heart and Lung Research Institute, The Ohio State University, Columbus, \\ Ohio
}

\begin{abstract}
The role of inflammation in idiopathic pulmonary fibrosis (IPF) is controversial. If inflammation were critical to the disease process, lung pathology would demonstrate an influx of inflammatory cells, and that the disease would respond to immunosuppression. Neither is true. The classic pathology does not display substantial inflammation, and no modulation of the immune system is effective as treatment. Recent data suggest that the pathophysiology of the disease is more a product of fibroblast dysfunction than of dysregulated inflammation. The role of inflammation in disease pathogenesis comes from pathology from atypical patients, biologic samples procured during exacerbations of the disease, and careful examination of biologic specimens from patients with stable disease. We suggest that inflammation is indeed a critical factor in IPF and propose five potential nontraditional mechanisms for the role of inflammation in the pathogenesis of IPF: the direct inflammatory hypothesis, the matrix hypothesis, the growth factor-receptor hypothesis, the plasticity hypothesis, and the vascular hypothesis. To address these, we review the literature exploring the differences in pathology, prognosis, and clinical course, as well as the role of cytokines, growth factors, and other mediators of inflammation, and last, the role of matrix and vascular supply in patients with IPF.
\end{abstract}

\section{THE CONTROVERSIAL ROLE OF INFLAMMATION IN HUMAN PULMONARY FIBROSIS}

The discussion of and the debate over the role of inflammation in idiopathic pulmonary fibrosis (IPF) is not new $(48,139)$. Initially, experts suggested that the fibrosis seen in IPF resulted from a robust alveolar and interstitial inflammatory response to an unknown insult. To conclude that inflammation is critical to the disease process, one assumes that lung pathology from patients with the disease has an influx of inflammatory cells. Moreover, an expectation exists that the disease responds to immunosuppression. Neither is true in IPF. Usual interstitial pneumonia (UIP) is the classic pathologic description of IPF. UIP is characterized by areas of normal lung intermixed with varying staged destruction of the interstitial space. This temporal heterogeneity with fibroblastic foci is the hallmark for UIP. Note that this description does not include or require the presence of an inflammatory cellular infiltrate. Additionally, no effective modulation of the immune system improves mortality or alters the inexorable clinical course. The only debatable beneficial medical treatments are from very small studies and case series in which the antioxidant $\mathrm{N}$-acetylcysteine (NAC) $(15,36)$ and anticoagulation $(86)$ demonstrated benefits. Therefore, by classic measures, no clear causal role is known for active

Address reprint requests to: Clay Marsh, M.D., 473 W. $12^{\text {th }}$ Ave, The Dorothy M. Davis Heart and Lung Research Institute, Suite 201, Columbus, OH 43210, E-mail: clay.marsh@osumc.edu. 
inflammation in IPF. Additionally, new insights into the disease, like identifying genetic polymorphisms in genes regulating telomere length in patients with $\operatorname{IPF}(12,144)$ and identifying reduced calveolin-1 in fibroblasts from patients with IPF (150), suggest the dominant role of fibroblast dysfunction in IPF as opposed to an inflammatory process.

However, hints exist that inflammation has a distinct role in the disease. In addition to UIP, nonspecific interstitial pneumonia (NSIP) can be seen in surgical lung biopsy samples in patients diagnosed clinically with IPF. NSIP has more pathologic inflammation and, when seen in biopsy samples, can affect prognosis (18). Furthermore, patients with IPF have periods of acute decline called exacerbations $(78,115)$. During exacerbations, an influx of inflammatory cells is seen in bronchoalveolar (BAL) fluid and in open lung biopsies from affected patients. Last, numerous proinflammatory mediators and cytokines are found in BAL and lung biopsies from patients with active IPF.

In this review, we propose that inflammation is indeed a critical factor in IPF. However, we speculate that the mechanism of inflammation in this disease may be nontraditional. We offer five hypotheses for inflammation: the direct inflammatory hypothesis, the matrix hypothesis, the growth factor-receptor hypothesis, the plasticity hypothesis, and the vascular hypothesis. To address these, we review the literature exploring the differences in pathology, prognosis, and clinical course, as well as the role of cytokines, growth factors, and other mediators of inflammation, and the role of matrix and vascular supply in patients with IPF. We propose that inflammation, although not in a traditional sense, plays a critical role in the pathogenesis of IPF.

\section{DEFINING AND DIAGNOSING IDIOPATHIC PULMONARY FIBROSIS (IPF)}

Idiopathic pulmonary fibrosis (IPF) is characterized by inexorable, progressive fibrosis involving the interstitial space, existing between the vascular endothelium and alveolar epithelium. In this critical space, gas is exchanged between red blood cells circulating in blood vessels and alveolar air. When this space is deranged by inflammatory cells or collagen deposition, gas exchange is impaired, and functional alveolar units are reduced (54). Collectively, diseases that affect this space are called interstitial lung diseases (ILDs) and were initially described by Hamman and Rich in the 1940s (56). The disease first described by Hamman and Rich is a rapidly progressive interstitial pneumonia, now called acute interstitial pneumonia (AIP) (140). IPF is one of the most common forms of ILD whose chronic progressive course has an elusive pathophysiology, has no effective treatment options (other than organ transplantation), and is uniformly fatal $(54,78,149)$.

IPF is a confusing term with myriad definitions over the years. This has led to variability in the literature about the specific lung-disease categories being evaluated. IPF is also referred to as cryptogenic fibrosing alveolitis (CFA), "lone CFA" (CFA not associated with the presence of collagen vascular disease), and UIP (3). Recently, several international expert groups attempted to standardize the diagnostic, classification, and treatment protocols $(2,3)$. Despite this work, controversy remains about the diagnosis and the clinical approach (41).

Currently, the diagnosis of IPF can be made without lung biopsy when the patient is initially seen with typical clinical and radiologic findings. However, the gold standard remains pathologically diagnosing UIP $(2,3,74,129)$. Pathologically, UIP lung biopsies show temporal heterogeneity of fibrosis and characteristic fibroblastic foci. Interestingly, a diagnosis of NSIP is made by temporal homogeneity and inflammatory cells in the biopsy and is associated with a better prognosis than is UIP (18). Importantly, when UIP and NSIP are found in the same biopsy, patients tend to reflect the prognosis of UIP alone (43). These data support the concept that direct inflammation is not likely a key biologic mechanism of UIP. A question of efficacy exists in performing a lung biopsy on patients with advanced IPF, as surgical biopsy in these 
patients carries considerable risk (84), and a question exists of the clinical significance of histologic classification (42). Currently, treatment of the disease also is controversial. Some experts recommend a brief trial of immunosuppression, with continuation if a response is seen. However, if no response occurs, physicians usually stop the treatment and suggest seeking supportive care, enrollment in clinical trials, or addition of antioxidants like $N$-acetylcysteine (NAC) to the regimen. Others recommend only supportive treatment, pulmonary rehabilitation, and referral for lung transplantation.

As mentioned, many older studies are difficult to summarize and interpret because of the varying pathology and heterogeneity of the disease and diagnosis. Additionally, most available research data are based on small series of mixed groups of patients with fibrosis resulting from systemic conditioning ranging from sarcoidosis to scleroderma, drug-induced fibrosis to agents like amiodarone and bleomycin, and postinfectious disease. By taking the information obtained from patients with UIP/IPF and defining animal models that resemble the disease pathogenesis and pathology, we can obtain a better understanding of the disease.

\section{MODELS OF PULMONARY FIBROSIS: HUMAN AND ANIMAL CORRELATIONS}

One of the ongoing debates in animal models of pulmonary fibrosis concerns the relative dissimilarity of the observed phenotype to human IPF. Researchers use various methods to induce pulmonary fibrosis in mice, and the results have identified numerous cells, cytokines, growth factors, and profibrotic factors that play a role in the pathogenesis of this disease. Researchers have also turned to other human diseases and environmental insults that result in fibrosis and have made correlations to the pathophysiology of IPF.

The "naturally" occurring model of pulmonary fibrosis, and one of the earliest studied, is the tyrosine phosphatase SHP-1-deficient (motheaten) mouse, which has severe organ inflammation, including within the lung (127). However, this model reflects more inflammation than fibrosis. Numerous other models have followed, each with its own benefits and shortcomings. Some mimic cytokine profiles, and some mimic pathology, whereas others mimic cell populations seen in human IPF. None recreates the entire pathologic picture.

Most models are based on known causes of fibrosis in humans and are replicated in animals, but no one standard protocol for inducing pulmonary fibrosis in animals resembles that for pulmonary fibrosis in patients with UIP/IPF. Researchers use many different approaches, especially in rats and mice, to dissect pathogenic mechanisms. The most widely used method of inducing experimental pulmonary fibrosis in mice is the administration of intratracheal bleomycin. Other models include fluorescein isothiocyanate (FITC), silica, asbestos, and irradiation. We briefly review these models.

\section{Bleomycin}

It is recognized that a subset of patients that receive bleomycin have pulmonary fibrosis in an age- and dose-dependent manner that can pathologically resemble UIP $(4,5,91,117)$. Hence, many researchers adapted it use as an experimental means of inducing pulmonary fibrosis in animals. Bleomycin is a cancer chemotherapeutic agent that is given systemically in the treatment of squamous cell carcinomas, testicular cancer, esophageal carcinoma, germ cell ovarian tumors, and gestational trophoblastic neoplasms, as well as Hodgkin disease and nonHodgkin lymphoma, malignant effusions of the peritoneum, pericardium, and pleura, thyroid tumors, and osteosarcomas.

Mice have subsequently been treated with bleomycin to induce fibrosis as a model for human IPF $(6,72)$. A single dose of intratracheal (IT) bleomycin is the most prevalent stimulus to 
induce pulmonary fibrosis in mice, and the relative simplicity makes this approach very attractive. However, pathologically, IT bleomycin does not resemble human IPF. Alternatively, intraperitoneal (IP), intravenous (IV), and intra-nasal (IN) challenges of fibrosis-inducing stimuli have been used, with each differing in the duration of the exposure and the areas of the lung that are affected. We record the pathologic pattern of lung injury and fibrosis in Table 1 for stimuli inducing pulmonary fibrosis in mice.

One of the major disadvantages of the lack of a standard approach to inducing pulmonary fibrosis in animals is the intrinsic variability of results and limited application to the human disease. Administration of bleomycin by using a single systemic injection or repeated bleomycin dosing gives a pathologic distribution more closely resembling human UIP, with subpleural collagen deposition and lung injury. The IT delivery method gives predominantly bronchocentric injury (30). Bleomycin challenge is a well-established model of murine pulmonary fibrosis and is used to investigate the pathophysiology of IPF.

\section{Irradiation and free radicals}

Irradiation is a well-described cause of lung injury and fibrosis in humans $(33,104)$. Irradiation induces free radical production and DNA damage, leading to apoptotic cell death. Free radicals induced by radiation stimulate inflammation and cytokine release in the target tissue. Radiation pneumonitis is characterized by lung edema from enhanced vascular permeability and increased recruitment of leukocytes and increased numbers of alveolar macrophages (100). This cascade can lead to fibrosis in the radiation field and can result in restrictive lung disease $(40,80,128)$.

A late manifestation of disease can result in pathology outside the original radiation field (11). This "out-of-field" disease is from a systemic manifestation of the radiation (11). Treatment for fibrosis within and outside the field of radiation is effective. Steroid treatment is beneficial for challenged mice (53) and humans, but the pathology tends to recur after treatment is stopped (11). Pentoxifylline, which decreases neutrophil adhesion and activation, can be used for radiation-induced pneumonitis and fibrosis in humans (113). Pentoxifylline may work in bleomycin-induced murine inflammation $(39,85)$ but has not been trialed in patients with IPF. Other drugs like amifostine (a free radical scavenger and cisplatin metabolizer), Gleevec (an Abl tyrosine kinase inhibitor), and captopril (an angiotensinconverting enzyme inhibitor) have also been trialed with minimal or unproven success.

Like bleomycin, irradiation and other murine models inducing free radical production in the lung have been used in murine models. Thoracic radiation to mice results in lymphocyte and macrophage recruitment and is used as a model for lung injury (71). Oxygen toxicity has also been implicated in pulmonary fibrosis. Persistently elevated levels of oxygen in the lung increase the incidence of lung fibrosis and are associated with the bronchopulmonary dysplasia seen in neonates (38). Hyperoxia leads to reactive oxygen species production, exhausting cellular antioxidant and oxygen-scavenging mechanisms, leaving the cells vulnerable to free radical-mediated damage (45). In rats, hyperoxia leads to pulmonary edema and to fibrosis (8). It is possible that genetic mutations caused by free radicals may be protective; this is the subject of ongoing investigation $(81,82)$. In human disease, NAC has some benefit in the treatment of IPF (36), implying a potential role of oxidants and free radicals in the pathophysiology of native IPF.

\section{Inhaled irritants: silicosis, asbestosis, and cigarette smoking}

Inhaled silica and asbestos can lead to lung disease, including fibrosis. Silica, in the crystalline form, is toxic, as it accumulates in alveolar macrophages, induces cytokine release, and results in an inflammatory response leading to fibrosis $(1,123)$. Exposure to larger doses results in 
acute silicosis, resulting in secondary alveolar proteinosis, and can lead to massive fibrosis (1). Chronic silicosis results in a slow, progressive disease. It results in nodule formation, fibrosis, and increased macrophage infiltration (123). Murine models of silica exposure are used to study lung fibrosis. These studies suggest a necessary inflammatory component with a critical role for alveolar and interstitial mononuclear phagocytes $(7,21,22)$. Silica can be delivered intranasally $(26,70)$, intratracheally $(7,62,87,109)$, or via oral aspiration $(87)$ to develop murine lung disease. As with bleomycin, debate exists as to the optimal route of administration (87).

Asbestos also induces lung injury. Asbestos fibers are deposited on the epithelial cells of the airways and alveolar space. Here, macrophages engulf the fibers, become activated, and initiate the inflammatory cascade that ultimately results in fibrosis (124). Asbestos exposure results in slowly developing subpleural fibrosis over decades, with eventual nodule formation and characteristic diaphragmatic pleural-based fibrosis and calcifications. Asbestos exposure can lead to malignant mesothelioma, and when associated with smoking, asbestosis can lead to bronchogenic lung cancer (57). Asbestos delivery to the lung has been used in the mouse to cause lung fibrosis (23). As with bleomycin, numerous routes of administration include aerosolization $(23,35,119,125,136)$ and intratracheal administration (143). In the investigation of asbestos-induced fibrosis in mice, various cytokines and mediators of inflammation and cell signaling have been implicated, including the MAP kinase pathway (125) and ERK1/2 (35), protein kinase C (136), MMPs (143), TNF- $\alpha$ (90), and oxidative stress $(69,103)$. All indicate an inflammatory role for asbestos-mediated inflammation.

Smoking is causally related to desquamative interstitial pneumonia (DIP), respiratory bronchiolitis-related interstitial lung disease (RB-ILD), and pulmonary Langerhans cell histiocytosis (LCH); however, its role in UIP is unclear $(59,106)$. Epidemiologically, a smoking history is frequently elicited in patients with UIP/IPF and appears to worsen the disease course (134), but its role in the pathogenesis is debated. It is likely that smoking alters the oxidative stress in the lungs and may work through this mechanism (120). In addition, smoking reduces telomere length, hastening cellular senescence (102). Smad signaling may also play a role in this interaction between smoking and IPF (49), and this is especially important because IPF is causally associated with increased levels of active TGF- $\beta$, which signals through the Smad pathway.

Smoking has been combined with bleomycin in guinea pigs, and data suggest that smoking alone can induce fibrosis. The combination of both agents leads to worsened fibrosis, thought to be mediated by alterations in TIMP, IL-4, and eosinophils (32). Interestingly, conflicting data suggest that smoking is protective in hamsters given intratracheal bleomycin (111). The role of smoking and IPF is currently under investigation, and their interactions must be further elucidated.

\section{Inflammatory profile: cells}

When researchers study pulmonary fibrosis in animals, the type of agent being used (bleomycin, FITC, silica, asbestos, irradiation) and how it is administered (IT, IP, IV, IN, aerosol, thoracic exposure) result in different inflammatory profiles. Patients with IPF have various immune cells within the lung, including alveolar macrophages, neutrophils, and lymphocytes, all of which contribute to the pathogenesis of this disease. In animal models, these cells also play a significant role in varying degrees in the pathologic outcome.

As evident in Table 2, regardless of the route of administration, alveolar macrophages are the predominant cell type in the lung after agent-induced lung injury in mice. The significance of these cells is thoroughly discussed in a recent review, detailing the contribution of alveolar 
macrophages to lung disease and their importance as immune effector cells within the lung in patients with IPF (121).

In summary, numerous murine models of pulmonary fibrosis exist. Although no single model accurately mimics the disease, one can use information from each model to get a better sense of how various cells, cytokines, growth factors, and other mediators of inflammation and fibrosis interact to create various phenotypes. As we uncover a more thorough understanding of these interactions and combine those data with information from patients with IPF, a better understanding of the disease can be achieved.

As stated, we believe that inflammation is important in human IPF; five hypotheses may explain the role of inflammation in this disease (Fig. 1).

\section{HYPOTHESES FOR POTENTIAL ROLES OF INFLAMMATION IN THE DEVELOPMENT OF PULMONARY FIBROSIS}

\section{Direct inflammation hypothesis (Fig. 2)}

Most data suggest that a direct role of inflammation is not present in the pathogenesis of UIP/ IPF. Supporting this argument, immunosuppression is not an effective therapy for patients with IPF. ${ }^{67} \mathrm{Ga}$, a nuclear medicine agent, is largely taken up by macrophages and is a measure of inflammation in the lung (50). ${ }^{67} \mathrm{Ga}$ uptake in the lungs of patients with IPF is decreased after corticosteroid treatment, suggesting that steroid treatment is effective in reducing lung inflammation. Despite the effective reduction of inflammation in the lung, no correlation is found with survival or improvement in clinical outcome in IPF patients treated with steroids (52), suggesting that a direct role for inflammation in basal IPF is unlikely.

In contrast to the lack of benefit of steroids in basal IPF, immunosuppression with steroids may be effective in acute exacerbations of the disease, particularly those spawned by viral infection. Despite this clinical observation, steroid treatment for acute exacerbations in IPF has not been demonstrated in large trials $(31,75)$. One reason for this dearth of information is the heterogeneity of acute exacerbations and the lack of agreement on clear diagnostic criteria (34). Evaluating patients with exacerbation is problematic, and some centers will not obtain BAL fluid from patients with exacerbation, as bronchoscopy with BAL may exacerbate IPF (61).

Inflammatory cell influx in surgical lung biopsies predicts a worse outcome (115). Lung samples from patients with an accelerated course of IPF overexpress genes involved in repair/ remodeling, morphogenesis, oxidative stress, migration/proliferation, and genes from fibroblasts/smooth muscle cells, including adenosine-2B receptor and prominin-1/CD133, and matrix metalloproteinase-9 (134). These data do not specifically address the issue of a role for inflammation in the basal disease, but suggest that inflammation may play an important role in acute exacerbations of IPF.

\section{Proinflammatory cytokines in IPF}

Patterns of cytokines may provide clues to the predominant cell types critical to various stages of disease. Th2 cytokines such as IL-4, IL-5, and IL-13, are significantly higher in cellular cultures from IPF patients than from normal volunteers (46). T cells from these patients also display differences from those of normal patients. For example, IL-10 suppresses T-cell proliferation in alveolar macrophages from healthy volunteers (smokers and nonsmokers), but not from patients with IPF. In addition, differences in cytokine and cytokine receptors are noted in pathologic tissue from patients with UIP and NSIP. For example, IL-13 receptor levels are elevated in lung biopsies from UIP patients compared with those with NSIP (68). Differences 
in receptor subunit localization also are seen. Fibroblastic foci in patients with UIP strongly stain for IL-4R $\alpha$ and IL-13R $\alpha 2$. Localized expression of IL-4R $\alpha$ is also seen in surgical lung biopsies from patients with NSIP but not in other groups (68).

Cytokines that are involved in neutrophil, monocytes, and lymphocyte chemotaxis and activation are elevated in tissue or fluid from the lungs of patients with IPF. These cytokines include macrophage inflammatory protein- $1 \alpha$ (MIP-1 $\alpha /$ CCL3) (137,138), MCP-1/CCL2 (27), and IL-8 $(27,108)$. Cytokines involved in systemic diseases that mimic IPF may also provide clues to underlying pathology. CCL7/MCP-3 is elevated in serum from patients with systemic scleroderma, and the levels correlate with disease severity, including the extent of pulmonary fibrosis (157). CCL7/MCP-3 interacts with CCR1, CCR2, and CCR3 receptors and has a spectrum of action encompassing T cells, NK cells, eosinophils, dendritic cells (DC), and mononuclear phagocytes. Angiogenesis is also affected by several proangiogenic (VEGF, ENA-78, GRO- $\alpha$, IL-8) and antiangiogenic (MIG, CTGF) cytokines, which are elevated in serum, BAL fluid, and lung tissue in patients with IPF $(10,24)$.

Importantly, we recently demonstrated that macrophage colony-stimulating factor (M-CSF) is elevated in BAL fluid of patients with IPF, and that M-CSF directed mononuclear phagocyte recruitment and CCL2 production in a bleomycin model of murine lung fibrosis (13). Other mediators of inflammation may also be important, such as MMP-2, which is activated in IPF. Pro-MMP-2 is activated by membrane-type MMP (MT-MMP), of which the several subtypes appear to be upregulated in patients with IPF. These include MT1- and MT2-MMP (alveolar epithelial), as well as MT3-MMP, which is upregulated by TGF- $\beta$ (47)

\section{TGF- $\beta$ and CTGF}

In addition to inflammatory cells producing chemokines and cytokines to direct repair and remodeling in the lung, these cells also are important producers and activators of profibrotic proteins like TGF- $\beta$ and connective tissue growth factor (CTGF). Active TGF- $\beta$ is a multifunctional cytokine that is causally linked to animal models of lung fibrosis. TGF- $\beta$ is produced as a latent complex with active TGF- $\beta$ sequestered by the latency-associated peptide (LAP). Macrophages activate TGF- $\beta$ through direct interactions with the latent complex or through the production of oxidants or proteases that also lead to TGF- $\beta$ activation. Activation of latent TGF- $\beta$ by the integrin $\alpha_{\mathrm{v}} \beta_{6}$ is important in epithelial to mesenchymal transformation (79), and mice deficient in the $\beta_{6}$ integrin are protected from bleomycin-induced pulmonary fibrosis (105). Active TGF- $\beta$ is important in a number of models of pulmonary fibrosis but does not induce sustained lung fibrosis alone (159). Importantly, TGF- $\beta$ works with CTGF to induce and sustain lung fibrosis in animal models (155). CTGF is in the CCN (CYR61/CTGF/ NOV) gene family and is produced by inflammatory cells, including macrophages, and by fibroblasts in response to active TGF- $\beta$. The combination of active TGF- $\beta$ and CTGF augments and sustains lung fibrosis, through inducing expression and release of collagen from tissue fibroblasts $(19,64,65,88)$.

\section{Cellularity in IPF}

The last 40 years has seen exploration of almost every inflammatory cell type in the genesis and progression of IPF. In the 1970s, the lymphocytes and eosinophils were identified as mediators of the disease. In the 1980's neutrophils were identified as key contributors to the lung pathology in $\operatorname{IPF}(63,135,152,158)$, and investigators found that elevated neutrophil numbers in BAL fluid were typical in patients with the disease $(55,122,152,158)$. The 1990 s work demonstrated the importance of macrophages, cytokines, and "cross-talk" between cells $(63,112,133,137,138)$. Now researchers are focusing on the mononuclear phagocyte, the fibroblast, the myofibroblast, the fibrocyte, the epithelial cell, and the role of the lung microenvironment in IPF. 
The eosinophil also appears to play an important role in pulmonary fibrosis. Increased numbers of eosinophils in IPF patient lung biopsies or BAL fluid $(122,158)$ increase the risk of progressive lung disease $(60,118)$. The eosinophil may promote lung injury via eosinophil cationic protein (ECP) release, which is increased in IPF, suggesting that eosinophil activation is part of the inflammatory process in IPF (55).

Lymphocyte infiltration in areas of honeycombed lung in patients with UIP correlates positively with survival $(114,116,141)$, and these lymphocytes display elevated CD4/CD8 Tcell ratios, highlighting the importance of this subpopulation in IPF. Such features are also seen in NSIP and indicate improved prognosis (76). Lymphocytes likely play a more dominate role in the infiltrative lesions seen in NSIP, whereas other inflammatory cells like neutrophils are involved in the fibrotic lesions of UIP $(135,152)$. Plasma cells infiltrating the honeycombed areas of fibrosis in surgical lung biopsies from patients with UIP also correlate with survival $(114,116,141)$.

Other cells like neutrophils also play a role in pulmonary fibrosis. Neutrophil infiltration is a characteristic feature of the alveolitis of IPF, with high levels of neutrophil elastase found in the lung parenchyma (158). Therefore, neutrophils likely play an important role in the pathogenesis of IPF (107). Sputum and BAL samples from patients with IPF show elevated levels of IL-8, an important neutrophil chemoattractant and proangiogenic molecule, which correlates with lung-function impairment and prognosis $(14,60)$. Neutrophilic infiltration in the honeycombed fibrotic areas of surgical lung biopsies from patients with UIP correlates inversely with survival $(114,116,141)$. Alveolar macrophages are elevated in BAL samples (133) and are critical in promoting neutrophil influx $(63,112,137,138)$ through MIP-1 $\alpha /$ CCL3 and IL-8 release $(137,138)$. In addition to the role of leukocytes in the disease, epithelial cell proliferation and transition to fibroblasts or myofibroblasts to the lung are critical, leading to the concept of epithelial-mesenchymal transition of cells in the remodeled lung $(79,154)$.

It is very unlikely that a single cell type, cytokine, or growth factor is responsible for the phenotype of IPF. Rather, complex interactions between numerous cytokines and cells probably drive the phenotype. The delicate balance between pro- and antiinflammatory and fibrotic mediators becomes unbalanced and leads to the pulmonary fibrosis phenotype. Does the matrix within the lung parenchyma house this deposition of cytokines and growth factors left from an original inflammatory insult eventually induce a profibrotic environment? This concept has been previously suggested $(48,131,132)$.

\section{Matrix hypothesis}

IPF appears to be a disease of repeated lung injury and altered repair/remodeling. Experts agree that dysregulated deposition and clearance of collagen in a repeated wound-healing-like response characterizes the pathologic picture. However, the mechanisms leading to abnormal collagen deposition and repeated lung injury are not known. We speculate that deposits of growth factors, cytokines, and other profibrotic and inflammatory proteins within the lung matrix of patients with IPF drive the disease (Fig. 3). Some examples to support this hypothesis. First, the proteoglycans decorin and biglycan found in the matrix modulate the activity of TGF$\beta$ in pulmonary fibrosis (83). Moreover, TGF- $\beta$ itself is matrix bound and may play an important role of inducing pulmonary fibrosis and EMT via integrin activation of TGF- $\beta(73,79,105)$.

Similarly, CTGF is matrix bound and is critical in directing fibrosis. Bound CTGF may combine with active TGF- $\beta$ to promote fibroblasts to produce collagen I and III. M-CSF is also matrix deposited and directs mononuclear phagocyte recruitment and activation $(110,148)$. Furthermore, proliferating smooth muscle cells express M-CSF receptors and are activated by M-CSF. M-CSF also induces the fibroblast recruitment factors CCL2 in humans and CCL12 
in mice (13). The appearance of fibroblastic foci is a hallmark of IPF, and these cells are likely recruited and activated by growth factors and cytokines in the matrix.

Several other growth factors are embedded in the extracellular matrix to facilitate cellular functions, such as cell proliferation and differentiation. These factors include IGF-1, TNF- $\alpha$, FGF, VEGF, IL-1 $\beta$, PDGF, and EGF $(44,142,155)$, which may influence and regulate fibrosis, angiogenesis, and tissue repair.

\section{Growth factor-receptor hypothesis}

As mentioned, the observed lack of response to antiinflammatory therapies in IPF dampens enthusiasm for implicating inflammation in IPF. Interestingly, mononuclear phagocytes and the growth factors M-CSF and the chemokine CCL2 play a causal role in bleomycin-induced pulmonary fibrosis in mice (13). In addition, both M-CSF and CCL2 are elevated in BAL fluid from patients with IPF, suggesting that these cytokines may play an important role in human disease. It is important to note that M-CSF directly stimulates monocytes to produce CCL2 and CCL12, which appear to play important roles in pulmonary fibrosis after bleomycin challenge in mice. Importantly, both M-CSF and CCL2 induce mononuclear phagocyte chemotaxis. In addition to recruiting mononuclear phagocytes, CCL2 attracts fibrocytes, and CCL12 recruits fibroblasts to contribute to lung repair and remodeling.

These observations are relevant to the issue of tissue inflammation, repair, and remodeling. Specifically, responsiveness to M-CSF is largely governed by M-CSF receptor expression, a member of the growth factor-receptor family. Importantly, M-CSF-, insulin-like growth factor (IGF)- (51), and PDGF-receptor expression and activation (89) increase in the presence of dexamethasone (29), suggesting that a number of cells activated by these growth factors are unaffected by glucocorticoids. The expression of the growth-factor receptor on the surface of responding cells governs the biologic effect of growth factors. Cellular activation and survival by M-CSF binding to its cognate receptor involves the production of intracellular oxidants and the activation of several biochemical pathways, including ROS, PI 3-K/Akt, PI 3-K/Erk, and p38 $(17,151)$. Antioxidants like NAC reduce M-CSF-induced cellular activation and survival, suggesting that antioxidant strategies may target these activated cells. These data create a scenario by which M-CSF-induced cellular activation is augmented in the presence of steroid treatment. Similarly, PDGF (9) and insulin-like growth factor (146) are implicated in the pathogenesis of IPF and are similarly affected by corticosteroids.

\section{Plasticity hypothesis}

As mentioned, the expression of the M-CSF receptor is not blocked by steroids, but antioxidants like NAC reduce M-CSF-mediated cellular activation and survival $(29,151)$. Although M-CSF receptor expression is usually limited to mononuclear phagocytes, in certain situations, other cells express this receptor. For example, proliferating smooth muscle cells (67) and neutrophils (130) can express the M-CSF receptor. This observation suggests a new dimension of typical inflammation: plasticity of mononuclear phagocytes into cells engaged in tissue repair and remodeling (Fig. 4). This may extend to other mesenchymal cells in the tissue microenvironment, as cells displaying macrophage markers like CD14, M-CSF-R, or CCR2 are found in these compartments.

It is recognized that, in addition to the M-CSF receptor, monocytes or progenitor cells circulating with the $\mathrm{CD} 14+$ population retain plasticity to respond to environmental cues. For example, CD14+ cells, which typically mark monocyte/macrophages, give rise to osteoblasts, skeletal myoblasts, chondrocytes, and adipocytes $(28,37,77,126,145,147)$. Thus, inflammatory cells may participate in lung repair/remodeling in classic and nonclassic pathways. 
We speculate that in the tissue microenvironment surrounding areas of remodeled lung in IPF, inflammatory cells function in atypical manners to facilitate fibrosis. Careful studies to address this hypothesis have not been done and could give new insights into the roles of these cells in tissue repair and remodeling. These data suggest the possibility that inflammation is indeed part of lung fibrosis, and that inflammation cannot be ruled out as a mechanism in this disease solely on the basis of failure of patients to respond to steroids or the lack of finding inflammatory cells in pathologic tissues.

\section{Vascular hypothesis}

Systemic autoimmune diseases like scleroderma provide insight into the pathogenesis of IPF, because scleroderma-related lung disease often pathologically resembles IPF. Autoimmune antibodies deposited in the vascular endothelium are seen in scleroderma-related pulmonary fibrosis. Factors shown to be increased in patients with scleroderma with lung fibrosis include CTGF, KL-6, surfactant protein-D, tissue inhibitor of metalloproteinase 2 (TIMP-2), CCL2/ MCP-1, CCL3/MIP- $1 \alpha$, soluble interleukin- 6 receptors, antiendothelial cell antibodies, and anti-DNA topoisomerase I antibodies (153). Additionally, patients with IPF have increased ddimers and possible microvascular injury (86). Does an underlying vascular injury in IPF occur that results in cytokine trafficking, subsequently resulting in the fibrotic phenotype?

Circulating antinuclear antibodies (ANA) are described in patients with IPF (122). We showed that IPF patients have vascular injury and antiendothelial cell antibodies in their serum compared with normal patients (63). Moreover, we found antibody deposition in the vascular endothelium and endothelial cell necrosis in pathologic lung tissue in patients with UIP (93). Similar autoantibodies are seen in response to viral infections that can lead to pulmonary fibrosis (94). The activation of fibroblasts has been described in scleroderma (16), and this process appears to be related to deposition of autoantibodies $(66,92,156)$. We previously reported that deposited IgG drives the survival of human monocytes through M-CSF production, IL-8, and CCL2/MCP-1 (96-98), all implicated in IPF.

Additionally, we found that injecting bleomycin systemically (IP) compared with IT in mice gave a pathologic picture of subpleural lower lobe distribution of fibrosis, similar to that seen in patients with IPF. Taken together, we speculate that inflammatory cells may target the vascular endothelium in IPF (Fig. 5) and be blind to routine pathologic analysis, as they are washed away in processing.

\section{SUMMARY: COMBINING OUR KNOWLEDGE FROM THE BENCH AND BEDSIDE}

In human IPF and murine models of pulmonary fibrosis, inflammation likely plays a role in disease genesis and progression. However, the mechanisms of involvement are not well characterized. Many different models are used to study pulmonary fibrosis in animals; however, the varied agents and routes of administration of the stimuli have resulted in nonuniformity of the investigative techniques. This only confuses the role of inflammation in the pathogenesis of this disease.

Extensive human data support the role of inflammation. Innumerable cytokines and cell types have been implicated in the disease, but their exact role remains elusive. Further delineation of the specific role of inflammation in human IPF is complicated by the lack of natural history of pathologic materials from patients. By using new high-throughput techniques like gene and protein arrays, as well as systems biology analysis, we anticipate a better understanding of the pathophysiology of the disease and, more important, defining new diagnostic and therapeutic options for patients with IPF. 


\section{Acknowledgments}

The first two authors contributed equally to this article. Funding for the salaries of the authors of this article was supported in part by the NIH 2R01HL067176, P01HL70294, 1R01HL085109, 5R01HL67176-04, 5R01HL066108-04.

\section{ABBREVIATIONS}

\section{BAL}

bronchoalveolar lavage

EMT

epithelial-mesenchymal transformation

\section{ILD}

interstitial lung disease

IN

intranasal

IP

intraperitoneal

IPF

idiopathic pulmonary fibrosis

IT

intratracheal

IV

intravenous

NAC

$N$-acetylcysteine

NSIP

nonspecific interstitial pneumonia

UIP

usual interstitial pneumonia

\section{References}

1. American Thoracic Society Committee of the Scientific Assembly on Environmental and Occupational Health. Adverse effects of crystalline silica exposure. Am J Respir Crit Care Med 1997;155:761-768. [PubMed: 9032226]

2. American Thoracic Society. Idiopathic pulmonary fibrosis: diagnosis and treatment: international consensus statement: American Thoracic Society (ATS), and the European Respiratory Society (ERS). Am J Respir Crit Care Med 2000;161:646-664. [PubMed: 10673212]

3. American Thoracic Society/European Respiratory Society. International Multidisciplinary Consensus Classification of the Idiopathic Interstitial Pneumonias: this joint statement of the American Thoracic Society (ATS), and the European Respiratory Society (ERS) was adopted by the ATS Board of Directors, June 2001 and by The ERS Executive Committee, June 2001. Am J Respir Crit Care Med 2002;165:277-304. [PubMed: 11790668]

4. Adamson IY. Drug-induced pulmonary fibrosis. Environ Health Perspect 1984;55:25-36. [PubMed: 6203733] 
5. Adamson IY. Pulmonary toxicity of bleomycin. Environ Health Perspect 1976;16:119-125. [PubMed: 65280]

6. Adamson IY, Bowden DH. The pathogenesis of bleomycin-induced pulmonary fibrosis in mice. Am J Pathol 1974;77:185-197. [PubMed: 4141224]

7. Adamson IY, Bowden DH. Role of polymorphonuclear leukocytes in silica-induced pulmonary fibrosis. Am J Pathol 1984;117:37-43. [PubMed: 6486244]

8. Al-Motabagani MA. Histological changes in the alveolar structure of the rat lung after exposure to hyperoxia. Ital J Anat Embryol 2005;110:209-223. [PubMed: 16536052]

9. Antoniades HN, Bravo MA, Avila RE, Galanopoulos T, Neville-Golden J, Maxwell M, Selman M. Platelet-derived growth factor in idiopathic pulmonary fibrosis. J Clin Invest 1990;86:1055-1064. [PubMed: 2170444]

10. Antoniou KM, Tzouvelekis A, Alexandrakis MG, Sfiridaki K, Tsiligianni I, Rachiotis G, Tzanakis N, Bouros D, Milic-Emili J, Siafakas NM. Different angiogenic activity in pulmonary sarcoidosis and idiopathic pulmonary fibrosis. Chest 2006;130:982-988. [PubMed: 17035428]

11. Arbetter KR, Prakash UB, Tazelaar HD, Douglas WW. Radiation-induced pneumonitis in the “nonirradiated" lung. Mayo Clin Proc 1999;74:27-36. [PubMed: 9987529]

12. Armanios MY, Chen JJ, Cogan JD, Alder JK, Ingersoll RG, Markin C, Lawson WE, Xie M, Vulto I, Phillips JA 3rd, Lans-dorp PM, Greider CW, Loyd JE. Telomerase mutations in families with idiopathic pulmonary fibrosis. N Engl J Med 2007;356:1317-1326. [PubMed: 17392301]

13. Baran CP, Opalek JM, McMaken S, Newland CA, O'Brien JM Jr, Hunter MG, Bringardner BD, Monick MM, Brigstock DR, Stromberg PC, Hunninghake GW, Marsh CB. Important roles for MCSF, CCL2 and mononuclear phagocytes in the pathogenesis of pulmonary fibrosis. Am J Respir Crit Care Med 2007;176:78-89. [PubMed: 17431224]

14. Beeh KM, Beier J, Kornmann O, Buhl R. Neutrophilic inflammation in induced sputum of patients with idiopathic pulmonary fibrosis. Sarcoidosis Vasc Diffuse Lung Dis 2003;20:138-143. [PubMed: 12870724]

15. Behr J, Maier K, Degenkolb B, Krombach F, Vogelmeier C. Antioxidative and clinical effects of high-dose $\mathrm{N}$-acetylcysteine in fibrosing alveolitis: adjunctive therapy to maintenance immunosuppression. Am J Respir Crit Care Med 1997;156:1897-1901. [PubMed: 9412572]

16. Beon M, Harley RA, Wessels A, Silver RM, Ludwicka-Bradley A. Myofibroblast induction and microvascular alteration in scleroderma lung fibrosis. Clin Exp Rheumatol 2004;22:733-742. [PubMed: 15638048]

17. Bhatt NY, Kelley TW, Khramtsov VV, Wang Y, Lam GK, Clanton TL, Marsh CB. Macrophagecolony-stimulating factor-induced activation of extracellular-regulated kinase involves phosphatidylinositol 3-kinase and reactive oxygen species in human monocytes. J Immunol 2002;169:6427-6434. [PubMed: 12444151]

18. Bjoraker JA, Ryu JH, Edwin MK, Myers JL, Tazelaar HD, Schroeder DR, Offord KP. Prognostic significance of histopathologic subsets in idiopathic pulmonary fibrosis. Am J Respir Crit Care Med 1998;157:199-203. [PubMed: 9445300]

19. Blom IE, Goldschmeding R, Leask A. Gene regulation of connective tissue growth factor: new targets for antifibrotic therapy? Matrix Biol 2002;21:473-482. [PubMed: 12392758]

20. Borges VM, Falcao H, Leite-Junior JH, Alvim L, Teixeira GP, Russo M, Nobrega AF, Lopes MF, Rocco PM, Davidson WF, Linden R, Yagita H, Zin WA, DosReis GA. Fas ligand triggers pulmonary silicosis. J Exp Med 2001;194:155-164. [PubMed: 11457890]

21. Bowden DH, Adamson IY. The role of cell injury and the continuing inflammatory response in the generation of silicotic pulmonary fibrosis. J Pathol 1984;144:149-161. [PubMed: 6094776]

22. Bowden DH, Hedgecock C, Adamson IY. Silica-induced pulmonary fibrosis involves the reaction of particles with interstitial rather than alveolar macrophages. J Pathol 1989;158:73-80. [PubMed: 2547046]

23. Bozelka BE, Sestini P, Gaumer HR, Hammad Y, Heather CJ, Salvaggio JE. A murine model of asbestosis. Am J Pathol 1983;112:326-337. [PubMed: 6311019]

24. Brigstock DR. Regulation of angiogenesis and endothelial cell function by connective tissue growth factor (CTGF) and cysteine-rich 61 (CYR61). Angiogenesis 2002;5:153-165. [PubMed: 12831056] 
25. Brody AR, Hill LH, Adkins B Jr, O’Connor RW. Chrysotile asbestos inhalation in rats: deposition pattern and reaction of alveolar epithelium and pulmonary macrophages. Am Rev Respir Dis 1981;123:670-679. [PubMed: 6267971]

26. Brown JM, Swindle EJ, Kushnir-Sukhov NM, Holian A, Metcalfe DD. Silica-directed mast cell activation is enhanced by scavenger receptors. Am J Respir Cell Mol Biol 2007;36:43-52. [PubMed: 16902192]

27. Car BD, Meloni F, Luisetti M, Semenzato G, Gialdroni-Grassi G, Walz A. Elevated IL-8 and MCP-1 in the bronchoalveolar lavage fluid of patients with idiopathic pulmonary fibrosis and pulmonary sarcoidosis. Am J Respir Crit Care Med 1994;149:655-659. [PubMed: 8118632]

28. Cavanagh LL, Saal RJ, Grimmett KL, Thomas R. Proliferation in monocyte-derived dendritic cell cultures is caused by progenitor cells capable of myeloid differentiation. Blood 1998;92:1598-1607. [PubMed: 9716587]

29. Chambers SK, Gilmore-Hebert M, Wang Y, Rodov S, Benz EJ Jr, Kacinski BM. Posttranscriptional regulation of colony-stimulating factor-1 (CSF-1) and CSF-1 receptor gene expression during inhibition of phorbol-ester-induced monocytic differentiation by dexamethasone and cyclosporin A: potential involvement of a destabilizing protein. Exp Hematol 1993;21:1328-1334. [PubMed: 8359233]

30. Chua F, Gauldie J, Laurent GJ. Pulmonary fibrosis: searching for model answers. Am J Respir Cell Mol Biol 2005;33:9-13. [PubMed: 15964990]

31. Churg A, Muller NL, Silva CI, Wright JL. Acute exacerbation (acute lung injury of unknown cause) in UIP and other forms of fibrotic interstitial pneumonias. Am J Surg Pathol 2007;31:277-284. [PubMed: 17255773]

32. Cisneros-Lira J, Gaxiola M, Ramos C, Selman M, Pardo A. Cigarette smoke exposure potentiates bleomycin-induced lung fibrosis in guinea pigs. Am J Physiol Lung Cell Mol Physiol 2003;285:L949-L956. [PubMed: 12842806]

33. Coggle JE, Lambert BE, Moores SR. Radiation effects in the lung. Environ Health Perspect 1986;70:261-291. [PubMed: 3549278]

34. Collard HR, Moore BB, Flaherty KR, Brown KK, Kaner RJ, King TE Jr, Lasky JA, Lloyd JE, Noth I, Olman MA, Raghu G, Roman J, Ryu JH, Zisman DA, Hunnighake GW, Colby TV, Egan JJ, Hansell DM, Johkoh T, Martinez FJ. Pulmonary perspective: acute exacerbations of idiopathic pulmonary fibrosis. Am J Respir Crit Care Med 2007;176:636-643. [PubMed: 17585107]

35. Cummins AB, Palmer C, Mossman BT, Taatjes DJ. Persistent localization of activated extracellular signal-regulated kinases (ERK1/2) is epithelial cell-specific in an inhalation model of asbestosis. Am J Pathol 2003;162:713-720. [PubMed: 12598305]

36. Demedts M, Behr J, Buhl R, Costabel U, Dekhuijzen R, Jansen HM, MacNee W, Thomeer M, Wallaert B, Laurent F, Nicholson AG, Verbeken EK, Verschakelen J, Flower CD, Capron F, Petruzzelli S, De Vuyst P, van den Bosch JM, Rodriguez-Becerra E, Corvasce G, Lankhorst I, Sardina M, Montanari M. High-dose acetylcysteine in idiopathic pulmonary fibrosis. N Engl J Med 2005;353:2229-2242. [PubMed: 16306520]

37. Diaz-Romero J, Gaillard JP, Grogan SP, Nesic D, Trub T, Mainil-Varlet P. Immunophenotypic analysis of human articular chondrocytes: changes in surface markers associated with cell expansion in monolayer culture. J Cell Physiol 2005;202:731-742. [PubMed: 15389573]

38. Elliott CG, Rasmusson BY, Crapo RO, Morris AH, Jensen RL. Prediction of pulmonary function abnormalities after adult respiratory distress syndrome (ARDS). Am Rev Respir Dis 1987;135:634638. [PubMed: 3548507]

39. Entzian P, Gerlach C, Gerdes J, Schlaak M, Zabel P. [Pentoxifylline inhibits experimental bleomycininduced fibrosing alveolitis]. Pneumologie 1997;51:375-380. [PubMed: 9221384]

40. Fay M, Tan A, Fisher R, Mac Manus M, Wirth A, Ball D. Dose-volume histogram analysis as predictor of radiation pneumonitis in primary lung cancer patients treated with radiotherapy. Int $\mathrm{J}$ Radiat Oncol Biol Phys 2005;61:1355-1363. [PubMed: 15817337]

41. Flaherty KR, Andrei A-C, King TE Jr, Raghu G, Colby TV, Wells A, Bassily N, Brown K, du Bois R, Flint A, Gay SE, Gross BH, Kazerooni EA, Knapp R, Louvar E, Lynch D, Nicholson AG, Quick J, Thannickal VJ, Travis WD, Vyskocil J, Wadenstorer FA, Wilt J, Toews GB, Murray S, Martinez 
FJ. Idiopathic interstitial pneumonia: do community and academic physicians agree on diagnosis? Am J Respir Crit Care Med 2007;175:1054-1060. [PubMed: 17255566]

42. Flaherty KR, Toews GB, Travis WD, Colby TV, Kazerooni EA, Gross BH, Jain A, Strawderman RL III, Paine R, Flint A, Lynch JP III, Martinez FJ. Clinical significance of histological classification of idiopathic interstitial pneumonia. Eur Respir J 2002;19:275-283. [PubMed: 11866008]

43. Flaherty KR, Travis WD, Colby TV, Toews GB, Kazerooni EA, Gross BH, Jain A, Strawderman RL, Flint A, Lynch JP, Martinez FJ. Histopathologic variability in usual and nonspecific interstitial pneumonias. Am J Respir Crit Care Med 2001;164:1722-1727. [PubMed: 11719316]

44. Fowlkes JL, Winkler MK. Exploring the interface between metallo-proteinase activity and growth factor and cytokine bioavailability. Cytokine Growth Factor Rev 2002;13:277-287. [PubMed: 12486879]

45. Freeman BA, Crapo JD. Hyperoxia increases oxygen radical production in rat lungs and lung mitochondria. J Biol Chem 1981;256:10986-10992. [PubMed: 7287745]

46. Furuie H, Yamasaki H, Suga M, Ando M. Altered accessory cell function of alveolar macrophages: a possible mechanism for induction of Th2 secretory profile in idiopathic pulmonary fibrosis. Eur Respir J 1997;10:787-794. [PubMed: 9150314]

47. Garcia-Alvarez J, Ramirez R, Sampieri CL, Nuttall RK, Edwards DR, Selman M, Pardo A. Membrane type-matrix metallo-proteinases in idiopathic pulmonary fibrosis. Sarcoidosis Vasc Diffuse Lung Dis 2006;23:13-21. [PubMed: 16933466]

48. Gauldie J. Pro: Inflammatory mechanisms are a minor component of the pathogenesis of idiopathic pulmonary fibrosis. Am J Respir Crit Care Med 2002;165:1205-1206. [PubMed: 11991866]

49. Gauldie J, Kolb M, Ask K, Martin G, Bonniaud P, Warburton D. Smad3 signaling involved in pulmonary fibrosis and emphysema. Proc Am Thorac Soc 2006;3:696-702. [PubMed: 17065376]

50. Gelrud LG, Arseneau JC, Milder MS, Kramer RJ, Swann SJ, Canellos GP, Johnston GS. The kinetics of 67gallium incorporation into inflammatory lesions: experimental and clinical studies. J Lab Clin Med 1974;83:489-495. [PubMed: 4204653]

51. Giorgino F, Smith RJ. Dexamethasone enhances insulin-like growth factor-I effects on skeletal muscle cell proliferation: role of specific intracellular signaling pathways. J Clin Invest 1995;96:1473-1483. [PubMed: 7544807]

52. Grijm K, Verberne HJ, Krouwels FH, Weller FR, Jansen HM, Bresser P. Semiquantitative ${ }^{67} \mathrm{Ga}$ scintigraphy as an indicator of response to and prognosis after corticosteroid treatment in idiopathic interstitial pneumonia. J Nucl Med 2005;46:1421-1426. [PubMed: 16157523]

53. Gross NJ, Narine KR, Wade R. Protective effect of corticosteroids on radiation pneumonitis in mice. Radiat Res 1988;113:112-119. [PubMed: 3340715]

54. Gross TJ, Hunninghake GW. Idiopathic pulmonary fibrosis. N Engl J Med 2001;345:517-525. [PubMed: 11519507]

55. Hallgren R, Bjermer L, Lundgren R, Venge P. The eosinophil component of the alveolitis in idiopathic pulmonary fibrosis: signs of eosinophil activation in the lung are related to impaired lung function. Am Rev Respir Dis 1989;139:373-377. [PubMed: 2536526]

56. Hammann LRA. Acute diffuse interstitial fibrosis of the lungs. Bull Johns Hopkins Hosp 1944;74:177-212.

57. Hammond EC, Selikoff IJ, Seidman H. Asbestos exposure, cigarette smoking and death rates. Ann N Y Acad Sci 1979;330:473-490. [PubMed: 294198]

58. Hattori N, Degen JL, Sisson TH, Liu H, Moore BB, Pandrangi RG, Simon RH, Drew AF. Bleomycininduced pulmonary fibrosis in fibrinogen-null mice. J Clin Invest 2000;106:1341-1350. [PubMed: 11104787]

59. Hidalgo A, Franquet T, Gimenez A, Bordes R, Pineda R, Madrid M. Smoking-related interstitial lung diseases: radiologic-pathologic correlation. Eur Radiol 2006;16:2463-2470. [PubMed: 16865368]

60. Hiwatari N, Shimura S, Sasaki T, Aikawa T, Ando Y, Ishihara H, Sekizawa K, Sasaki H, Takishima T. Prognosis of idiopathic pulmonary fibrosis in patients with mucous hypersecretion. Am Rev Respir Dis 1991;143:182-185. [PubMed: 1986676]

61. Hiwatari N, Shimura S, Takishima T, Shirato K. Bronchoalveolar lavage as a possible cause of acute exacerbation in idiopathic pulmonary fibrosis patients. Tohoku J Exp Med 1994;174:379-386. [PubMed: 7732520] 
62. Huaux F, Louahed J, Hudspith B, Meredith C, Delos M, Renauld JC, Lison D. Role of interleukin-10 in the lung response to silica in mice. Am J Respir Cell Mol Biol 1998;18:51-59. [PubMed: 9448045]

63. Hunninghake GW, Gadek JE, Lawley TJ, Crystal RG. Mechanisms of neutrophil accumulation in the lungs of patients with idiopathic pulmonary fibrosis. J Clin Invest 1981;68:259-269. [PubMed: 7251862]

64. Igarashi A, Bradham DM, Okochi H, Grotendorst GR. Connective tissue growth factor. J Dermatol 1992;19:642-643. [PubMed: 1293144]

65. Igarashi A, Okochi H, Bradham DM, Grotendorst GR. Regulation of connective tissue growth factor gene expression in human skin fibroblasts and during wound repair. Mol Biol Cell 1993;4:637-645. [PubMed: 8374172]

66. Ihn H, Sato S, Fujimoto M, Igarashi A, Yazawa N, Kubo M, Kikuchi K, Takehara K, Tamaki K. Characterization of autoantibodies to endothelial cells in systemic sclerosis (SSc): association with pulmonary fibrosis. Clin Exp Immunol 2000;119:203-209. [PubMed: 10606984]

67. Inaba T, Yamada N, Gotoda T, Shimano H, Shimada M, Momomura K, Kadowaki T, Motoyoshi K, Tsukada T, Morisaki N, Morisaki N, Yasushi S, Yoshida S, Takaku F, Yazaki Y. Expression of MCSF receptor encoded by c-fms on smooth muscle cells derived from arteriosclerotic lesion. J Biol Chem 1992;267:5693-5699. [PubMed: 1531986]

68. Jakubzick C, Choi ES, Kunkel SL, Evanoff H, Martinez FJ, Puri RK, Flaherty KR, Toews GB, Colby TV, Kazerooni EA, Gross BH, Travis WD, Hogaboam CM. Augmented pulmonary IL-4 and IL-13 receptor subunit expression in idiopathic interstitial pneumonia. J Clin Pathol 2004;57:477-486. [PubMed: 15113854]

69. Janssen YM, Marsh JP, Absher M, Borm PJ, Mossman BT. Increases in endogenous antioxidant enzymes during asbestos inhalation in rats. Free Radic Res Commun 1990;11:53-58. [PubMed: 1963619]

70. Jiao A, Fish SC, Mason LE, Schelling SH, Goldman SJ, Williams CM. A role for endothelial selectins in allergic and non-allergic inflammatory disease. Ann Allergy Asthma Immunol 2007;98:83-88. [PubMed: 17225725]

71. Johnston CJ, Williams JP, Elder A, Hernady E, Finkelstein JN. Inflammatory cell recruitment following thoracic irradiation. Exp Lung Res 2004;30:369-382. [PubMed: 15204829]

72. Jones AW, Reeve NL. Ultrastructural study of bleomycin-induced pulmonary changes in mice. $\mathbf{J}$ Pathol 1978;124:227-233. [PubMed: 82615]

73. Kasai H, Allen JT, Mason RM, Kamimura T, Zhang Z. TGF-beta1 induces human alveolar epithelial to mesenchymal cell transition (EMT). Respir Res 2005;6:56. [PubMed: 15946381]

74. Katzenstein AL, Myers JL. Idiopathic pulmonary fibrosis: clinical relevance of pathologic classification. Am J Respir Crit Care Med 1998;157:1301-1315. [PubMed: 9563754]

75. Keane J, Gochuico B, Kasznica JM, Kornfeld H. Usual interstitial pneumonitis responsive to corticosteroids following varicella pneumonia. Chest 1998;113:249-251. [PubMed: 9440602]

76. Keogh KA, Limper AH. Characterization of lymphocyte populations in nonspecific interstitial pneumonia. Respir Res 2005;6:137. [PubMed: 16287509]

77. Khazen W, M'Bika JP, Tomkiewicz C, Benelli C, Chany C, Achour A, Forest C. Expression of macrophage-selective markers in human and rodent adipocytes. FEBS Lett 2005;579:5631-5634. [PubMed: 16213494]

78. Kim DS, Collard HR, King TE Jr. Classification and natural history of the idiopathic interstitial pneumonias. Proc Am Thorac Soc 2006;3:285-292. [PubMed: 16738191]

79. Kim KK, Kugler MC, Wolters PJ, Robillard L, Galvez MG, Brumwell AN, Sheppard D, Chapman HA. Alveolar epithelial cell mesenchymal transition develops in vivo during pulmonary fibrosis and is regulated by the extracellular matrix. Proc Natl Acad Sci U S A 2006;103:13180-13185. [PubMed: 16924102]

80. Kim TH, Cho KH, Pyo HR, Lee JS, Zo JI, Lee DH, Lee JM, Kim HY, Hwangbo B, Park SY, Kim JY, Shin KH, Kim DY. Dose-volumetric parameters for predicting severe radiation pneumonitis after three-dimensional conformal radiation therapy for lung cancer. Radiology 2005;235:208-215. [PubMed: 15703313]

81. Kinnula VL, Crapo JD. Superoxide dismutases in the lung and human lung diseases. Am J Respir Crit Care Med 2003;167:1600-1619. [PubMed: 12796054] 
82. Kinnula VL, Fattman CL, Tan RJ, Oury TD. Oxidative stress in pulmonary fibrosis: a possible role for redox modulatory therapy. Am J Respir Crit Care Med 2005;172:417-422. [PubMed: 15894605]

83. Kolb M, Margetts PJ, Sime PJ, Gauldie J. Proteoglycans decorin and biglycan differentially modulate TGF-beta-mediated fibrotic responses in the lung. Am J Physiol Lung Cell Mol Physiol 2001;280:L1327-L1334. [PubMed: 11350814]

84. Kondoh Y, Taniguchi H, Kitaichi M, Yokoi T, Johkoh T, Oishi T, Kimura T, Nishiyama O, Kato K, du Bois RM. Acute exacerbation of interstitial pneumonia following surgical lung biopsy. Respir Med 2006;100:1753-1759. [PubMed: 16584880]

85. Kremer S, Breuer R, Lossos IS, Berkman N, Christensen TG, Connor MW, Goldstein RH, Or R. Effect of immunomodulators on bleomycin-induced lung injury. Respiration 1999;66:455-462. [PubMed: 10516543]

86. Kubo H, Nakayama K, Yanai M, Suzuki T, Yamaya M, Watanabe M, Sasaki H. Anticoagulant therapy for idiopathic pulmonary fibrosis. Chest 2005;128:1475-1482. [PubMed: 16162746]

87. Lakatos HF, Burgess HA, Thatcher TH, Redonnet MR, Hernady E, Williams JP, Sime PJ. Oropharyngeal aspiration of a silica suspension produces a superior model of silicosis in the mouse when compared to intratracheal instillation. Exp Lung Res 2006;32:181-199. [PubMed: 16908446]

88. Leask A, Abraham DJ. The role of connective tissue growth factor, a multifunctional matricellular protein, in fibroblast biology. Biochem Cell Biol 2003;81:355-363. [PubMed: 14663501]

89. Liu JY, Brass DM, Hoyle GW, Brody AR. TNF-alpha receptor knockout mice are protected from the fibroproliferative effects of inhaled asbestos fibers. Am J Pathol 1998;153:1839-1847. [PubMed: 9846974]

90. Liu JY, Brody AR. Increased TGF-beta1 in the lungs of asbestos-exposed rats and mice: reduced expression in TNF-alpha receptor knockout mice. J Environ Pathol Toxicol Oncol 2001;20:97-108. [PubMed: 11394717]

91. Luna MA, Bedrossian CW, Lichtiger B, Salem PA. Interstitial pneumonitis associated with bleomycin therapy. Am J Clin Pathol 1972;58:501-510. [PubMed: 4118423]

92. Magro CM, Morrison C, Pope-Harman A, Rothrauff SK, Ross P Jr. Direct and indirect immunofluorescence as a diagnostic adjunct in the interpretation of nonneoplastic medical lung disease. Am J Clin Pathol 2003;119:279-289. [PubMed: 12580000]

93. Magro CM, Waldman WJ, Knight DA, Allen JN, Nadasdy T, Frambach GE, Ross P, Marsh CB. Idiopathic pulmonary fibrosis related to endothelial injury and antiendothelial cell antibodies. Hum Immunol 2006;67:284-297. [PubMed: 16720208]

94. Magro CM, Wusirika R, Frambach GE, Nuovo GJ, Ferri C, Ross P Jr. Autoimmune-like pulmonary disease in association with parvovirus B19: a clinical, morphologic, and molecular study of 12 cases. Appl Immunohistochem Mol Morphol 2006;14:208-216. [PubMed: 16785792]

95. Manoury B, Nenan S, Guenon I, Lagente V, Boichot E. Influence of early neutrophil depletion on MMPs/TIMP-1 balance in bleomycin-induced lung fibrosis. Int Immunopharmacol 2007;7:900-911. [PubMed: 17499192]

96. Marsh CB, Gadek JE, Kindt GC, Moore SA, Wewers MD. Monocyte Fc gamma receptor cross-linking induces IL-8 production. J Immunol 1995;155:3161-3167. [PubMed: 7673729]

97. Marsh CB, Pomerantz RP, Parker JM, Winnard AV, Mazzaferri EL Jr, Moldovan N, Kelley TW, Beck E, Wewers MD. Regulation of monocyte survival in vitro by deposited IgG: role of macrophage colony-stimulating factor. J Immunol 1999;162:6217-6225. [PubMed: 10229867]

98. Marsh CB, Wewers MD, Tan LC, Rovin BH. Fc(gamma) receptor cross-linking induces peripheral blood mononuclear cell monocyte chemoattractant protein-1 expression: role of lymphocyte $\mathrm{Fc}$ (gamma)RIII. J Immunol 1997;158:1078-1084. [PubMed: 9013945]

99. Matsuse T, Teramoto S, Katayama H, Sudo E, Ekimoto H, Mitsuhashi H, Uejima Y, Fukuchi Y, Ouchi Y. ICAM-1 mediates lung leukocyte recruitment but not pulmonary fibrosis in a murine model of bleomycin-induced lung injury. Eur Respir J 1999;13:71-77. [PubMed: 10836326]

100. McDonald S, Rubin P, Phillips TL, Marks LB. Injury to the lung from cancer therapy: clinical syndromes, measurable endpoints, and potential scoring systems. Int J Radiat Oncol Biol Phys 1995;31:1187-1203. [PubMed: 7713782] 
101. Moore BB, Murray L, Das A, Wilke CA, Herrygers AB, Toews GB. The role of CCL12 in the recruitment of fibrocytes and lung fibrosis. Am J Respir Cell Mol Biol 2006;35:175-181. [PubMed: 16543609]

102. Morla M, Busquets X, Pons J, Sauleda J, MacNee W, Agusti AG. Telomere shortening in smokers with and without COPD. Eur Respir J 2006;27:525-528. [PubMed: 16507852]

103. Mossman BT, Marsh JP. Evidence supporting a role for active oxygen species in asbestos-induced toxicity and lung disease. Environ Health Perspect 1989;81:91-94. [PubMed: 2667992]

104. Movsas B, Raffin TA, Epstein AH, Link CJ Jr. Pulmonary radiation injury. Chest 1997;111:10611076. [PubMed: 9106589]

105. Munger JS, Huang X, Kawakatsu H, Griffiths MJ, Dalton SL, Wu J, Pittet JF, Kaminski N, Garat C, Matthay MA, Rifkin DB, Sheppard D. The integrin alpha v beta 6 binds and activates latent TGF beta 1: a mechanism for regulating pulmonary inflammation and fibrosis. Cell 1999;96:319-328. [PubMed: 10025398]

106. Nagai S, Hoshino Y, Hayashi M, Ito I. Smoking-related interstitial lung diseases. Curr Opin Pulmon Med 2000;6:415-419.

107. Obayashi Y, Yamadori I, Fujita J, Yoshinouchi T, Ueda N, Takahara J. The role of neutrophils in the pathogenesis of idiopathic pulmonary fibrosis. Chest 1997;112:1338-1343. [PubMed: 9367478]

108. Ogushi F, Tani K, Maniwa K, Ichikawa W, Tada H, Kawano T, Sone S. Interleukin-8 in bronchoalveolar lavage fluid of patients with diffuse panbronchiolitis or idiopathic pulmonary fibrosis. J Med Invest 1997;44:53-58. [PubMed: 9395718]

109. Ohtsuka Y, Wang XT, Saito J, Ishida T, Munakata M. Genetic linkage analysis of pulmonary fibrotic response to silica in mice. Eur Respir J 2006;28:1013-1019. [PubMed: 16837500]

110. Ohtsuki T, Suzu S, Hatake K, Nagata N, Miura Y, Motoyoshi K. A proteoglycan form of macrophage colony-stimulating factor that binds to bone-derived collagens and can be extracted from bone matrix. Biochem Biophys Res Commun 1993;190:215-222. [PubMed: 8422246]

111. Osanai K, Takahashi K, Suwabe A, Takada K, Ikeda H, Sato S, Yasui S. The effect of cigarette smoke on bleomycin-induced pulmonary fibrosis in hamsters. Am Rev Respir Dis 1988;138:12761281. [PubMed: 2462387]

112. Ozaki T, Hayashi H, Tani K, Ogushi F, Yasuoka S, Ogura T. Neutrophil chemotactic factors in the respiratory tract of patients with chronic airway diseases or idiopathic pulmonary fibrosis. Am Rev Respir Dis 1992;145:85-91. [PubMed: 1309969]

113. Ozturk B, Egehan I, Atavci S, Kitapci M. Pentoxifylline in prevention of radiation-induced lung toxicity in patients with breast and lung cancer: a double-blind randomized trial. Int J Radiat Oncol Biol Phys 2004;58:213-219. [PubMed: 14697441]

114. Papiris SA, Kollintza A, Kitsanta P, Kapotsis G, Karatza M, Milic-Emili J, Roussos C, Daniil Z. Relationship of BAL and lung tissue CD4+ and CD8+ T lymphocytes, and their ratio in idiopathic pulmonary fibrosis. Chest 2005;128:2971-2977. [PubMed: 16236974]

115. Parambil JG, Myers JL, Ryu JH. Histopathologic features and outcome of patients with acute exacerbation of idiopathic pulmonary fibrosis undergoing surgical lung biopsy. Chest 2005;128:3310-3315. [PubMed: 16304277]

116. Parra ER, Kairalla RA, Ribeiro de Carvalho CR, Eher E, Capelozzi VL. Inflammatory cell phenotyping of the pulmonary interstitium in idiopathic interstitial pneumonia. Respiration 2007;74:159-169. [PubMed: 17108669]

117. Parvinen LM, Kilkku P, Makinen E, Liukko P, Gronroos M. Factors affecting the pulmonary toxicity of bleomycin. Acta Radiol Oncol 1983;22:417-421. [PubMed: 6203333]

118. Peterson MW, Monick M, Hunninghake GW. Prognostic role of eosinophils in pulmonary fibrosis. Chest 1987;92:51-56. [PubMed: 3595249]

119. Quinlan TR, Marsh JP, Janssen YM, Leslie KO, Hemenway D, Vacek P, Mossman BT. Doseresponsive increases in pulmonary fibrosis after inhalation of asbestos. Am J Respir Crit Care Med 1994;150:200-206. [PubMed: 8025751]

120. Rahman I, Skwarska E, Henry M, Davis M, O'Connor CM, FitzGerald MX, Greening A, MacNee W. Systemic and pulmonary oxidative stress in idiopathic pulmonary fibrosis. Free Radic Biol Med 1999;27:60-68. [PubMed: 10443920] 
121. Reynolds HY. Lung inflammation and fibrosis: an alveolar macrophage-centered perspective from the 1970s to 1980s. Am J Respir Crit Care Med 2005;171:98-102. [PubMed: 15557133]

122. Reynolds HY, Fulmer JD, Kazmierowski JA, Roberts WC, Frank MM, Crystal RG. Analysis of cellular and protein content of broncho-alveolar lavage fluid from patients with idiopathic pulmonary fibrosis and chronic hypersensitivity pneumonitis. J Clin Invest 1977;59:165-175. [PubMed: 830661]

123. Rimal B, Greenberg AK, Rom WN. Basic pathogenetic mechanisms in silicosis: current understanding. Curr Opin Pulm Med 2005;11:169-173. [PubMed: 15699791]

124. Robledo R, Mossman B. Cellular and molecular mechanisms of asbestos-induced fibrosis. J Cell Physiol 1999;180:158-166. [PubMed: 10395285]

125. Robledo RF, Buder-Hoffmann SA, Cummins AB, Walsh ES, Taatjes DJ, Mossman BT. Increased phosphorylated extracellular signal-regulated kinase immunoreactivity associated with proliferative and morphologic lung alterations after chrysotile asbestos inhalation in mice. Am J Pathol 2000;156:1307-1316. [PubMed: 10751356]

126. Romagnani P, Annunziato F, Liotta F, Lazzeri E, Mazzinghi B, Frosali F, Cosmi L, Maggi L, Lasagni L, Scheffold A, Kruger M, Dimmeler S, Marra F, Gensini G, Maggi E, Romagnani S. CD14+CD34 low cells with stem cell phenotypic and functional features are the major source of circulating endothelial progenitors. Circ Res 2005;97:314-322. [PubMed: 16020753]

127. Rossi GA, Hunninghake GW, Kawanami O, Ferrans VJ, Hansen CT, Crystal RG. Motheaten mice: an animal model with an inherited form of interstitial lung disease. Am Rev Respir Dis 1985;131:150-158. [PubMed: 3966703]

128. Rubenstein JH, Richter MP, Moldofsky PJ, Solin LJ. Prospective prediction of post-radiation therapy lung function using quantitative lung scans and pulmonary function testing. Int J Radiat Oncol Biol Phys 1988;15:83-87. [PubMed: 3391829]

129. Ryu JH, Colby TV, Hartman TE. Idiopathic pulmonary fibrosis: current concepts. Mayo Clin Proc 1998;73:1085-1101. [PubMed: 9818046]

130. Sasmono RT, Ehrnsperger A, Cronau SL, Ravasi T, Kandane R, Hickey MJ, Cook AD, Himes SR, Hamilton JA, Hume DA. Mouse neutrophilic granulocytes express mRNA encoding the macrophage colony-stimulating factor receptor (CSF-1R) as well as many other macrophagespecific transcripts and can transdifferentiate into macrophages in vitro in response to CSF-1. J Leukoc Biol 2007;82:111-123. [PubMed: 17438263]

131. Schonherr E, Hausser HJ. Extracellular matrix and cytokines: a functional unit. Dev Immunol 2000;7:89-101. [PubMed: 11097204]

132. Schuppan D, Ruehl M, Somasundaram R, Hahn EG. Matrix as a modulator of hepatic fibrogenesis. Semin Liver Dis 2001;21:351-372. [PubMed: 11586465]

133. Schwartz DA, Helmers RA, Dayton CS, Merchant RK, Hunninghake GW. Determinants of bronchoalveolar lavage cellularity in idiopathic pulmonary fibrosis. J Appl Physiol 1991;71:16881693. [PubMed: 1761464]

134. Selman M, Carrillo G, Estrada A, Mejia M, Becerril C, Cisneros J, Gaxiola M, Perez-Padilla R, Navarro C, Richards T, Dauber J, King TE, Pardo A, Kaminski N. Accelerated variant of idiopathic pulmonary fibrosis: clinical behavior and gene expression pattern. PLoS ONE 2007;2:e482. [PubMed: 17534432]

135. Shindoh Y, Shimura S, Tomioka M, Aikawa T, Sasaki H, Takishima T. Cellular analysis in bronchoalveolar lavage fluids in infiltrative and fibrotic stages of idiopathic pulmonary fibrosis. Tohoku J Exp Med 1986;149:47-60. [PubMed: 3738917]

136. Shukla A, Lounsbury KM, Barrett TF, Gell J, Rincon M, Butnor KJ, Taatjes DJ, Davis GS, Vacek P, Nakayama KI, Nakayama K, Steele C, Mossman BT. Asbestos-induced peribronchiolar cell proliferation and cytokine production are attenuated in lungs of protein kinase C-delta knockout mice. Am J Pathol 2007;170:140-151. [PubMed: 17200189]

137. Standiford TJ, Rolfe MR, Kunkel SL, Lynch JP 3rd, Becker FS, Orringer MB, Phan S, Strieter RM. Altered production and regulation of monocyte chemoattractant protein-1 from pulmonary fibroblasts isolated from patients with idiopathic pulmonary fibrosis. Chest 1993;103:121S. [PubMed: 8428531] 
138. Standiford TJ, Rolfe MW, Kunkel SL, Lynch JP 3rd, Burdick MD, Gilbert AR, Orringer MB, Whyte RI, Strieter RM. Macrophage inflammatory protein-1 alpha expression in interstitial lung disease. J Immunol 1993;151:2852-2863. [PubMed: 8360496]

139. Strieter RM. Con: Inflammatory mechanisms are not a minor component of the pathogenesis of idiopathic pulmonary fibrosis. Am J Respir Crit Care Med 2002;165:1206-1207. [PubMed: 11991867]discussion 1207-1208

140. Suh GY, Kang EH, Chung MP, Lee KS, Han J, Kitaichi M, Kwon OJ. Early intervention can improve clinical outcome of acute interstitial pneumonia. Chest 2006;129:753-761. [PubMed: 16537878]

141. Tabuena RP, Nagai S, Tsutsumi T, Handa T, Minoru T, Mikuniya T, Shigematsu M, Hamada K, Izumi T, Mishima M. Cell profiles of bronchoalveolar lavage fluid as prognosticators of idiopathic pulmonary fibrosis/usual interstitial pneumonia among Japanese patients. Respiration 2005;72:490-498. [PubMed: 16210888]

142. Taipale J, Keski-Oja J. Growth factors in the extracellular matrix. FASEB J 1997;11:51-59. [PubMed: 9034166]

143. Tan RJ, Fattman CL, Niehouse LM, Tobolewski JM, Hanford LE, Li Q, Monzon FA, Parks WC, Oury TD. Matrix metalloproteinases promote inflammation and fibrosis in asbestos-induced lung injury in mice. Am J Respir Cell Mol Biol 2006;35:289-297. [PubMed: 16574944]

144. Tsakiri KD, Cronkhite JT, Kuan PJ, Xing C, Raghu G, Weissler JC, Rosenblatt RL, Shay JW, Garcia CK. Adult-onset pulmonary fibrosis caused by mutations in telomerase. Proc Natl Acad Sci U S A 2007;104:7552-7557. [PubMed: 17460043]

145. Uemura Y, Kobayashi M, Nakata H, Kubota T, Bandobashi K, Saito T, Taguchi H. Effects of GMCSF and M-CSF on tumor progression of lung cancer: roles of MEK1/ERK and AKT/PKB pathways. Int J Mol Med 2006;18:365-373. [PubMed: 16820947]

146. Uh ST, Inoue Y, King TE Jr, Chan ED, Newman LS, Riches DW. Morphometric analysis of insulinlike growth factor-I localization in lung tissues of patients with idiopathic pulmonary fibrosis. Am J Respir Crit Care Med 1998;158:1626-1635. [PubMed: 9817718]

147. Urbich C, Heeschen C, Aicher A, Dernbach E, Zeiher AM, Dimmeler S. Relevance of monocytic features for neovascularization capacity of circulating endothelial progenitor cells. Circulation 2003;108:2511-2516. [PubMed: 14581410]

148. Vedham V, Phee H, Coggeshall KM. Vav activation and function as a rac guanine nucleotide exchange factor in macrophage colony-stimulating factor-induced macrophage chemotaxis. Mol Cell Biol 2005;25:4211-4220. [PubMed: 15870290]

149. Walter N, Collard HR, King TE Jr. Current perspectives on the treatment of idiopathic pulmonary fibrosis. Proc Am Thorac Soc 2006;3:330-338. [PubMed: 16738197]

150. Wang XM, Zhang Y, Kim HP, Zhou Z, Feghali-Bostwick CA, Liu F, Ifedigbo E, Xu X, Oury TD, Kaminski N, Choi AM. Caveolin-1: a critical regulator of lung fibrosis in idiopathic pulmonary fibrosis. J Exp Med 2006;203:2895-2906. [PubMed: 17178917]

151. Wang Y, Zeigler MM, Lam GK, Hunter MG, Eubank TD, Khramtsov VV, Tridandapani S, Sen CK, Marsh CB. The role of the NADPH oxidase complex, p38 MAPK, and Akt in regulating human monocyte/macrophage survival. Am J Respir Cell Mol Biol 2007;36:68-77. [PubMed: 16931806]

152. Watters LC, Schwarz MI, Cherniack RM, Waldron JA, Dunn TL, Stanford RE, King TE. Idiopathic pulmonary fibrosis: pre-treatment bronchoalveolar lavage cellular constituents and their relationships with lung histopathology and clinical response to therapy. Am Rev Respir Dis 1987;135:696-704. [PubMed: 3826895]

153. White B. Evaluation and management of pulmonary fibrosis in scleroderma. Curr Rheumatol Rep 2002;4:108-112. [PubMed: 11890875]

154. Willis BC, Liebler JM, Luby-Phelps K, Nicholson AG, Crandall ED, du Bois RM, Borok Z. Induction of epithelial-mesenchymal transition in alveolar epithelial cells by transforming growth factor-beta1: potential role in idiopathic pulmonary fibrosis. Am J Pathol 2005;166:1321-1332. [PubMed: 15855634]

155. Winkler MK, Fowlkes JL. Metalloproteinase and growth factor interactions: Do they play a role in pulmonary fibrosis? Am J Physiol Lung Cell Mol Physiol 2002;283:L1-L11. [PubMed: 12060555]

156. Wusirika R, Ferri C, Marin M, Knight DA, Waldman WJ, Ross P Jr, Magro CM. The assessment of anti-endothelial cell antibodies in scleroderma-associated pulmonary fibrosis: a study of indirect 
immunofluorescent and Western blot analysis in 49 patients with scleroderma. Am J Clin Pathol 2003;120:596-606. [PubMed: 14560571]

157. Yanaba K, Komura K, Kodera M, Matsushita T, Hasegawa M, Takehara K, Sato S. Serum levels of monocyte chemotactic protein-3/CCL7 are raised in patients with systemic sclerosis: association with extent of skin sclerosis and severity of pulmonary fibrosis. Ann Rheum Dis 2006;65:124-126. [PubMed: 16344498]

158. Yasuoka S, Nakayama T, Kawano T, Ogushi F, Doi H, Hayashi H, Tsubura E. Comparison of cell profiles of bronchial and bronchoalveolar lavage fluids between normal subjects and patients with idiopathic pulmonary fibrosis. Tohoku J Exp Med 1985;146:33-45. [PubMed: 4024082]

159. Yoshida M, Sakuma J, Hayashi S, Abe K, Saito I, Harada S, Sakatani M, Yamamoto S, Matsumoto $\mathrm{N}$, Kaneda $\mathrm{Y}$, et al. A histologically distinctive interstitial pneumonia induced by over-expression of the interleukin 6, transforming growth factor beta 1, or platelet-derived growth factor B gene. Proc Natl Acad Sci U S A 1995;92:9570-9574. [PubMed: 7568174] 


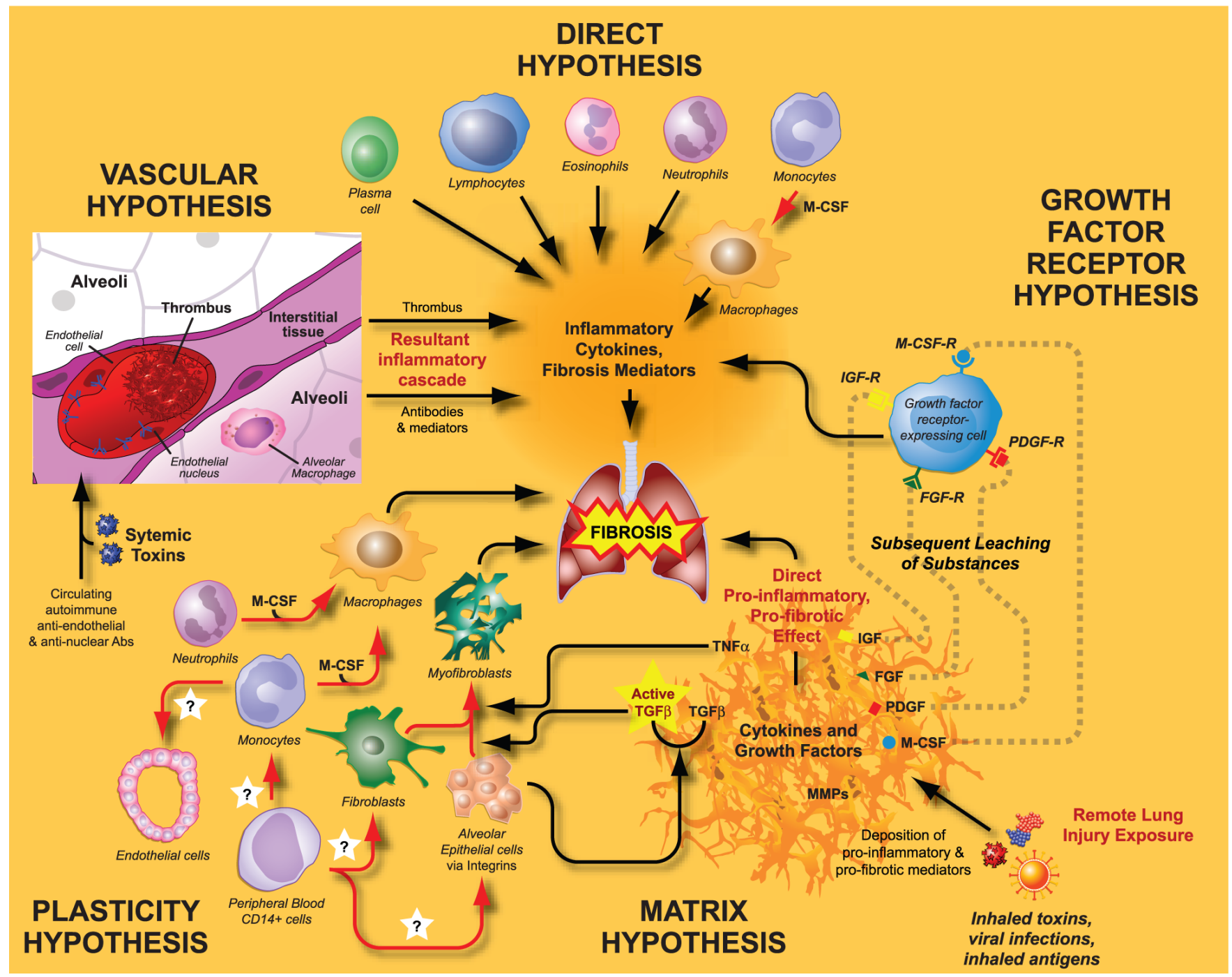

FIG. 1. Inflammation and pulmonary fibrosis

Numerous mediators of inflammation have been implicated in the pathogenesis of IPF. This review proposes five possible hypotheses for the pathogenesis of IPF. (A) The direct inflammation hypothesis suggests that inflammatory cells directly damage the tissues via substances like elastases, as well as cytokines and growth factors, which amplify this process. (B) The matrix hypothesis, in which inflammatory mediators released as a result of a remote injury are trapped in the pulmonary extracellular matrix. This leads to a prolonged and amplified wound-repair mechanism that results in the fibrotic phenotype. (C) The growth factor-receptor hypothesis suggests that some cell types with growth factor receptors proliferate unchecked in this environment, resulting in activation and amplification of the inflammatory cascade. Additionally, these receptors are upregulated in the presence of steroids, suggesting a rationale as to why immunosuppression is not successful in the treatment of IPF. (D) The plasticity hypothesis suggests that numerous cell types can differentiate into other cell types [for example, epithelial cells to mesenchymal cells (EMT), neutrophils and monocytes to macrophages], and this differentiation is a result of complex interactions of inflammatory mediators, growth factors, and other unidentified factors. These activated cells then mediate the fibrotic phenotype. (E) The vascular hypothesis suggests that some initial endothelial injury activates the inflammatory cascade with subsequent antibody deposition and resultant fibrosis. 
(For interpretation of the references to color in this figure legend, the reader is referred to the web version of this article at www.liebertonline.com/ars). 


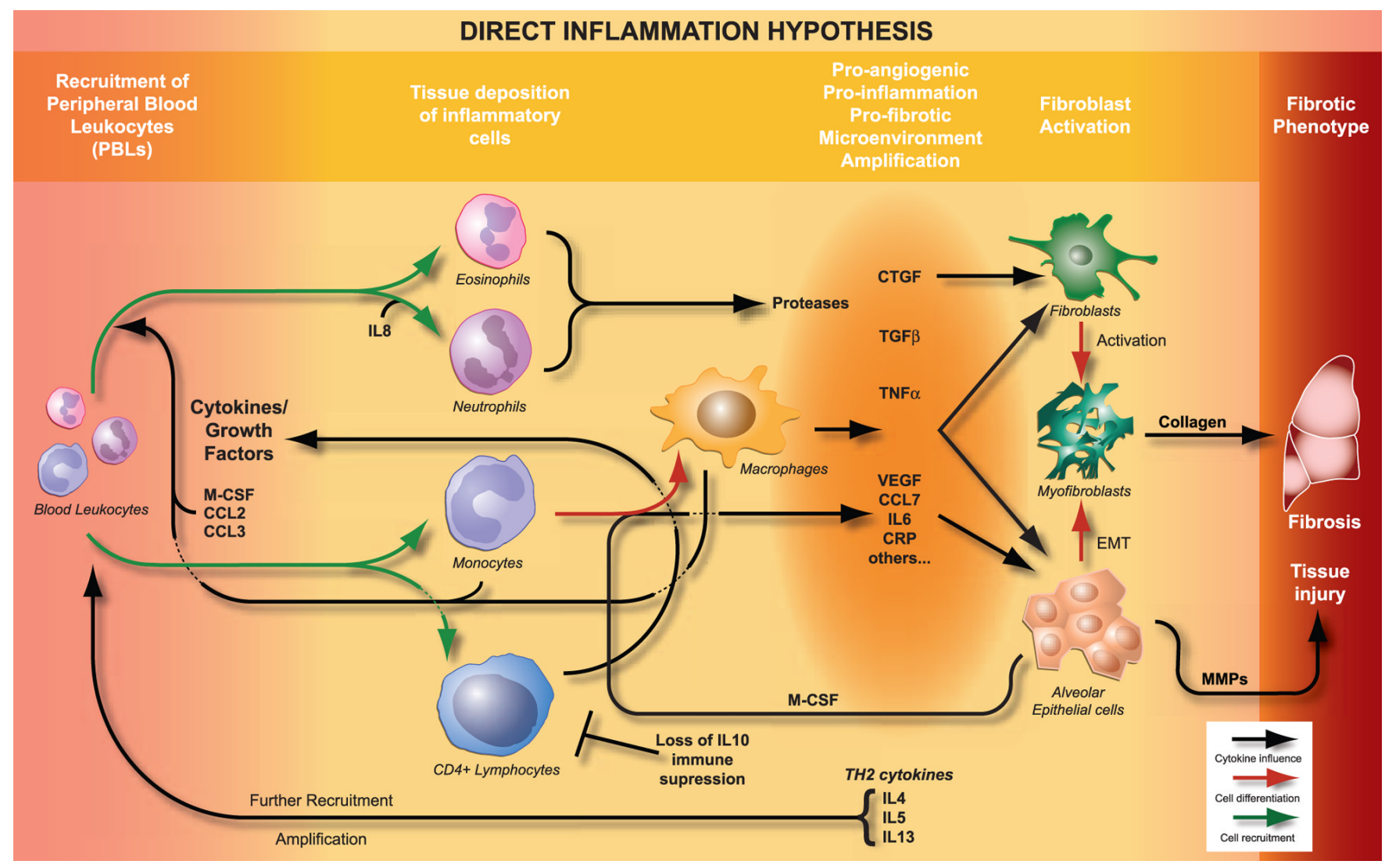

FIG. 2. Direct inflammation hypothesis

Inflammatory cell recruitment is believed to be mediated by chemokines like CCL2, CCL3, and IL8. These facilitate tissue deposition of inflammatory cells with further release of inflammatory mediators such as TGF- $\beta$, TNF- $\alpha$, and others with direct toxic effects (elastase, MMPs, and ECP). These proinflammatory cytokines are linked to profibrotic mediators like CTGF. These complex and incompletely understood interactions eventually result in myofibroblast activation and collagen deposition. Some of these pathways have been delineated, but numerous others still must be further investigated. Data to support this hypothesis largely revolve around the consistent elevation of these inflammatory mediators and cells that are found in pathologic lung biopsy samples, as well as BAL fluid from patients with IPF. (For interpretation of the references to color in this figure legend, the reader is referred to the web version of this article at www.liebertonline.com/ars). 


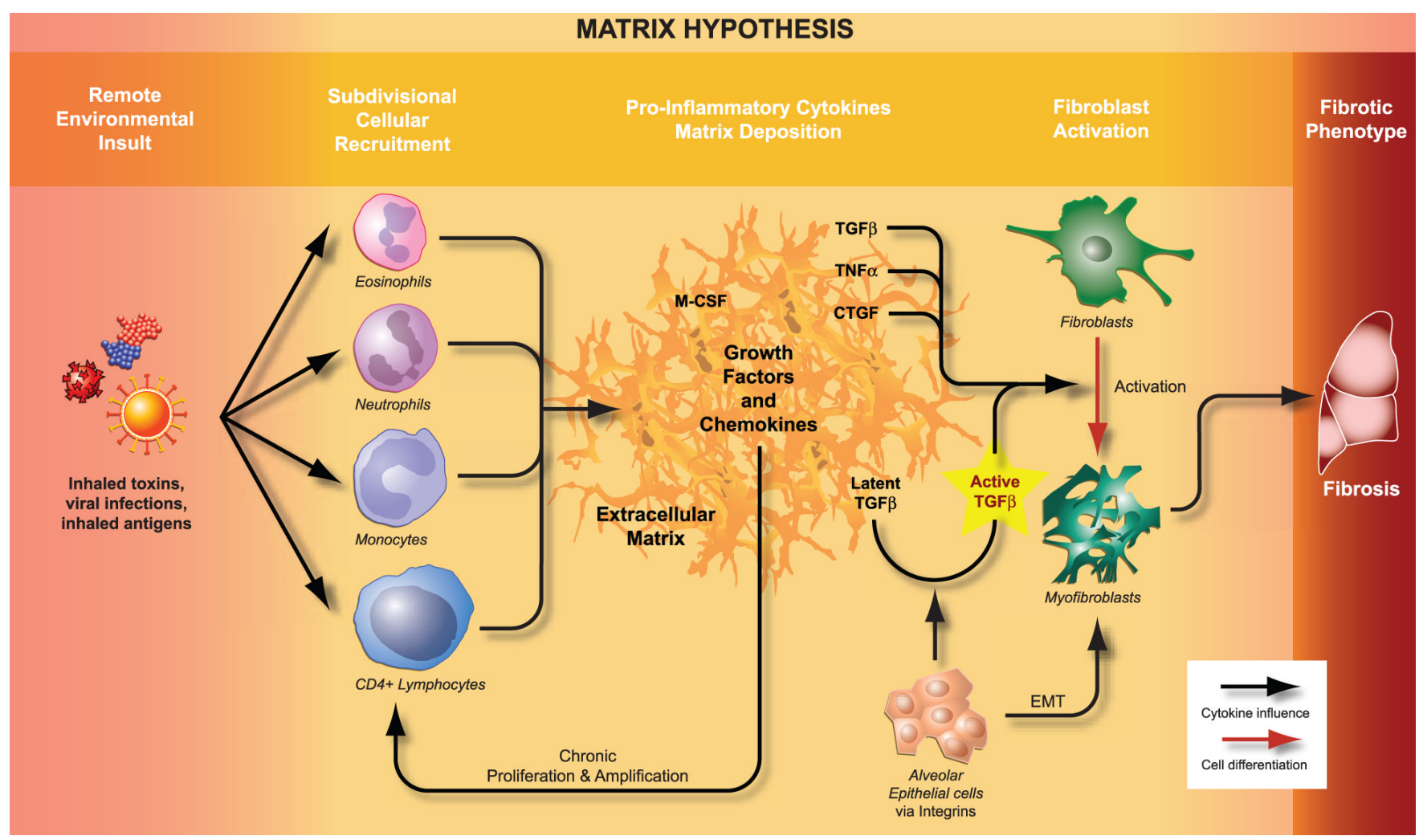

FIG. 3. Matrix hypothesis

Repeated and remote lung injury leads to inflammatory cell deposition in the pulmonary extracellular matrix. These cells deposit inflammatory mediators within the matrix where they are entrapped. Dysregulated deposition and clearance of collagen in a repeated wound repair/ remodel results in the pathologic findings. Proteoglycans and integrins activate free and matrixbound TGF- $\beta$ and CTGF (83). This results in fibroblast (myofibroblasts) activation and subsequent production of collagen type I and type III. Growth factors like IGF-1, TNF- $\alpha$, FGF, VEGF, IL-1 $\beta$, PDGF, EGF, and M-CSF $(44,142,155)$, as well as other mediators of inflammation, are matrix bound and deposited and result in cell recruitment and activation $(110,148)$. It is hypothesized that the fibroblastic foci seen in IPF are centers of matrix deposition of these mediators. (For interpretation of the references to color in this figure legend, the reader is referred to the web version of this article at www.liebertonline.com/ars). 


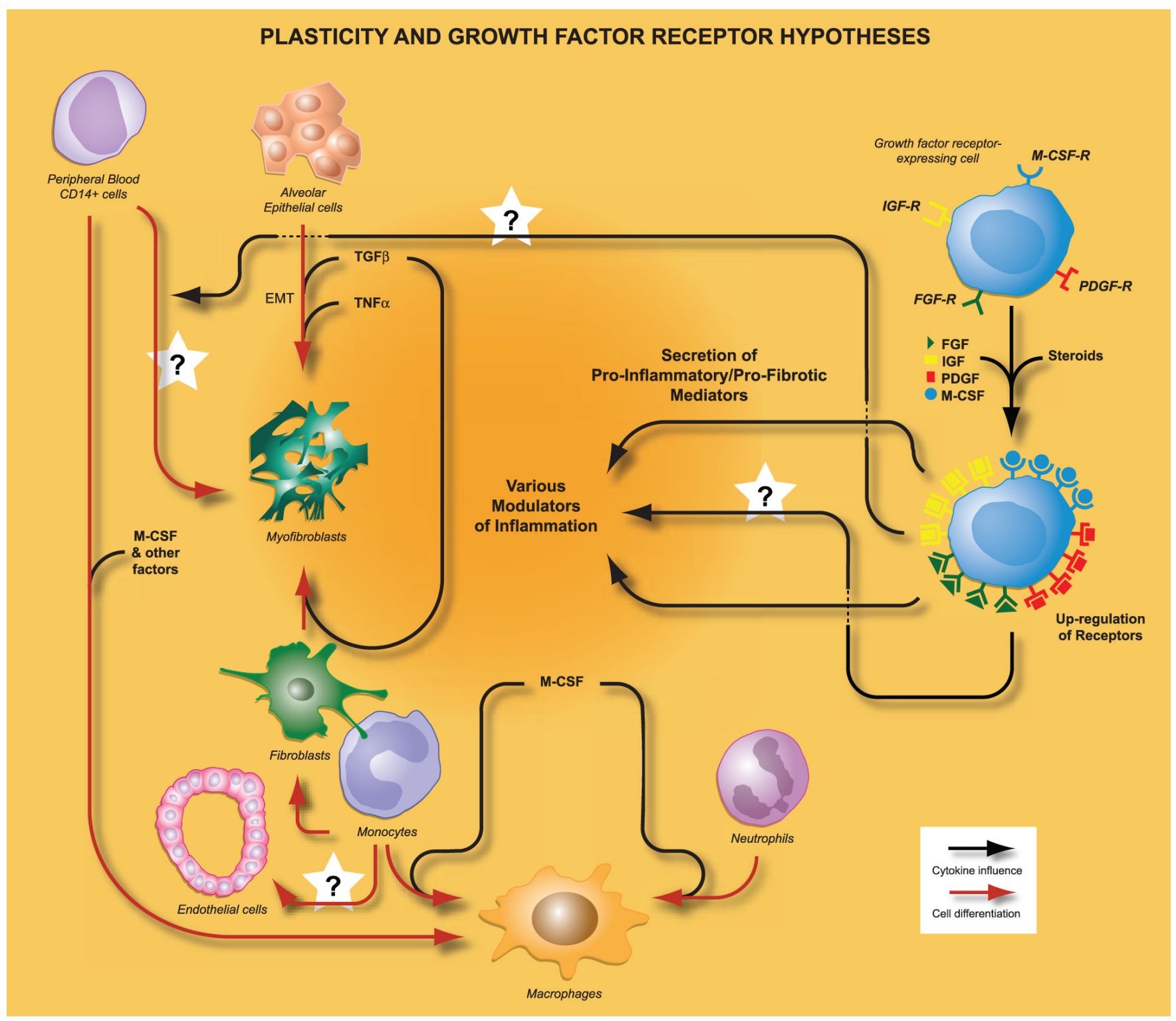

FIG. 4. Plasticity hypothesis and growth factor-receptor hypothesis

Numerous cells have been shown to undergo phenotypic transformation, and this is well documented. Monocytes can differentiate into macrophages, as can neutrophils. Epithelial cells have been shown to transform into mesenchymal cells, the basis of the epithelial-mesenchymal transformation hypothesis (EMT). We expand on these findings and propose that a CD14 $4^{+}$cell may be a progenitor cell that is capable of transforming from a peripheral blood cell to endothelial cells, macrophages, epithelial cells, fibroblasts, fibrocytes, or a combination of these. Additionally, growth factor-receptor expressing cells are resistant to traditional immunosuppression. Glucocorticoids have been shown to upregulate M-CSF receptors on other cells similar to macrophages, like osteoblasts. Once the growth-factor receptors are unregulated, this cell population is sensitized and results in increased cytokine secretion and subsequently activates numerous proinflammatory cascades as well as cross-talks with other inflammatory cell populations. (For interpretation of the references to color in this figure legend, the reader is referred to the web version of this article at www.liebertonline.com/ars). 


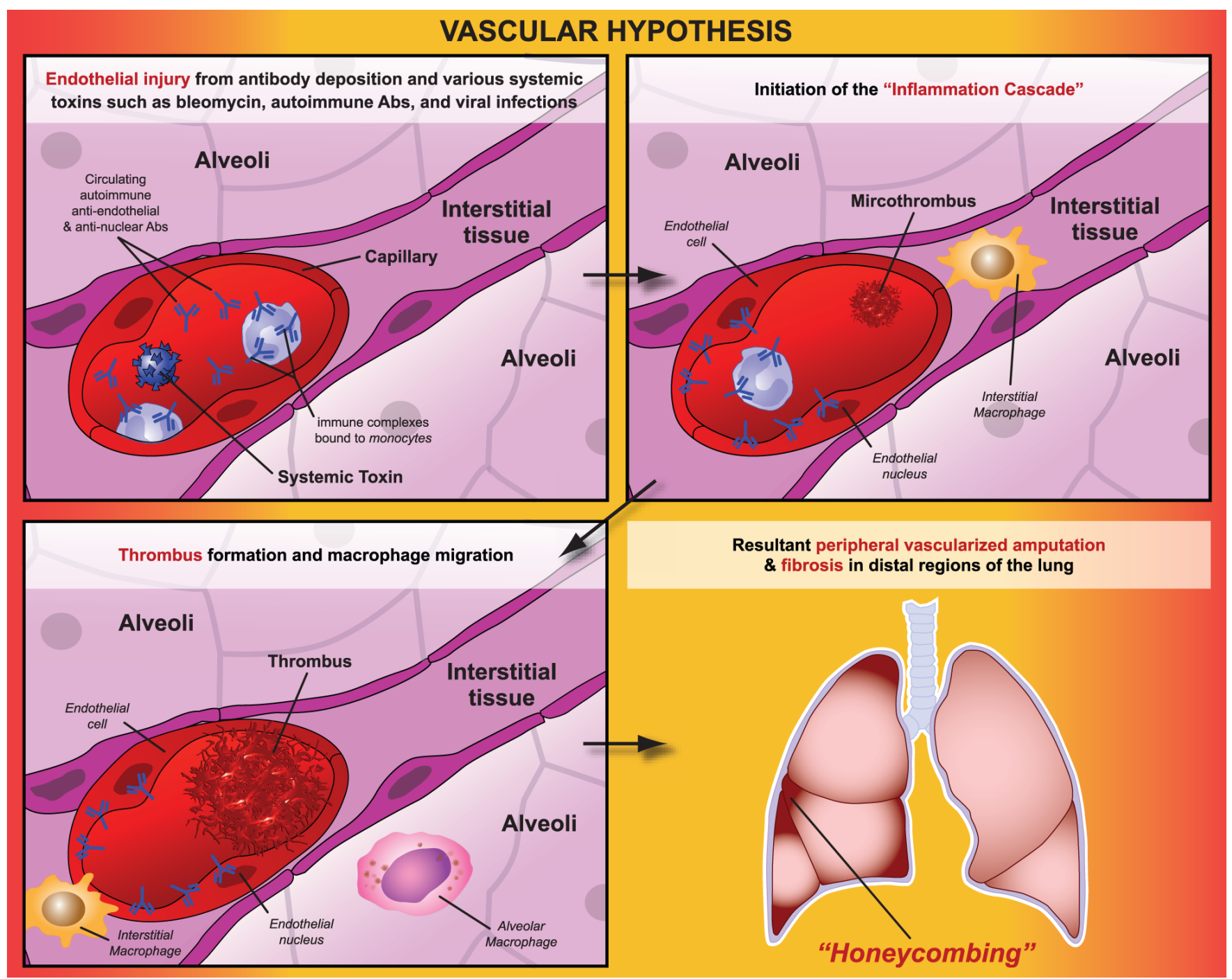

FIG. 5. Vascular hypothesis

Autoantibodies or systemic toxins result in underlying endothelial injury via monocyte recruitment and activation. Once the tissue is injured, antibodies initiate inflammatory cascades and subsequent cellular recruitment. Additionally, this endothelial injury results in a hypercoagulable state, as evidenced by elevated d-dimer and probable microthrombi (86). The antibodies that are seen in patients with UIP (93) may be circulating antinuclear antibodies (122), anti-endothelial cell antibodies (63), or be related to viral processes (94). Subsequent fibroblast activation may be a result of these autoantibodies $(66,92,156)$, as well as cellular growth and differentiation via M-CSF-dependent pathways (96-98). (For interpretation of the references to color in this figure legend, the reader is referred to the web version of this article at www.liebertonline.com/ars). 
Table 1

Pathology of Various Models for Fibrosis

\begin{tabular}{lllll}
\hline Agent & Route & Single/repeated dose & Duration (days) & Pathological pattern \\
\hline Asbestos(35,124) & Aerosolized & Repeated & $5-30$ & Bronchocentric \\
Asbestos(143) & IT & Single & $7-28$ & Bronchocentric \\
Bleomycin(95) & IN & Single & 14 & Both \\
Bleomycin(13) & IP & Repeated & $28-33$ & Subpleural \\
Bleomycin(58) & IT & Single & $14-21$ & Bronchocentric \\
Bleomycin(99) & IV & Single or Repeated & $14-49$ & Subpleural \\
FITC(101) & IT & Single & 21 & Bronchocentric \\
Radiation(71) & Thoracic & Single & Both & \\
Silica(87) & Aspiration & Single & Diffuse & \\
Silica(26,70) & IN & Repeated & Diffuse & Diffuse \\
Silica(20,62) & IT & Single & & \\
& & & &
\end{tabular}

IN, intranasal; IT, intratracheal; IP, intraperitoneal; IV, intravenous. 
Table 2

BAL Analysis of Inflammatory Cell Recruitment Following Lung Injury

\begin{tabular}{|c|c|c|c|c|}
\hline Agent & Route & Alveolar macrophages & Neutrophils & Lymphocytes \\
\hline Asbestos $(25,124)$ & Aerosol & 3 & 2 & 1 \\
\hline Asbestos $(25,124)$ & IT & 3 & 2 & 1 \\
\hline Bleomycin(95) & IN & 3 & 2 & 1 \\
\hline Bleomycin(13) & IP & 3 & 1 & 2 \\
\hline Bleomycin(58) & IT & 3 & 2 & 1 \\
\hline Bleomycin(99) & IV & 3 & 1 & 2 \\
\hline $\operatorname{FITC}(101)$ & IT & 3 & 2 & 1 \\
\hline Radiation(71) & Thoracic & 3 & 1 & 2 \\
\hline Silica(87) & Aspiration & 3 & 2 & 1 \\
\hline $\operatorname{Silica}(26,70)$ & IN & 3 & 3 & 1 \\
\hline Silica $(20,62)$ & IT & 3 & 2 & 1 \\
\hline
\end{tabular}

Least (1) to most numerous (3), IN, intranasal; IT, intratracheal; IP, intraperitoneal; IV, intravenous. 